Año 13.

Núm. 33
Revista de Investigación

Académica sin Frontera

ISSN: 2007-8870

https://revistainvestigacionacademicasinfrontera.unison.mx/index.php/RDIASF

Recibido el 28 de junio de 2020. Dictaminado mediante arbitraje favorablemente 18 de diciembre de 2020.

\title{
MANUFACTURE OF A DIE PROTOTYPE FOR DIDACTIC PURPOSES IN MECHATRONIC ENGINEERING
}

\section{MANUFACTURA DE UN PROTOTIPO DE TROQUEL PARA FINES DIDÁCTICOS EN INGENIERÍA MECATRÓNICA}

\author{
M.G.A.A. MONTIJO-VALENZUELA Eliel Eduardo ${ }^{1,2}$
}

eliel.montijo@ues.mx / https://orcid.org/0000-0001-8538-0767

DURAN-JIMENEZ Saul Daniel ${ }^{2}$

sauldanieldj4@gmail.com / https://orcid.org/0000-0002-8617-5738

ALTAMIRANO-RÍOS Luis Alberto

altamirano_rios97@ hotmail.com / https://orcid.org/0000-0003-3437-2446

PÉREZ-GÓMEZ, José Isae ${ }^{2}$

isaelpg_j@outlook.com / https://orcid.org/0000-0003-2107-8045

SALMÓN-AROCHI, Oscar ${ }^{2}$

osalmonarochi@gmail.com / https://orcid.org/0000-0003-2526-8022

\footnotetext{
${ }^{1}$ Universidad Estatal de Sonora - Unidad Académica Hermosillo, Jefatura de Ingeniería en Mecatrónica.

${ }^{2}$ Tecnológico Nacional de México/Instituto Tecnológico de Hermosillo, Departamento de Metal Mecánica, Ingeniería Mecatrónica.
}

\begin{abstract}
The objective of this research is to manufacture a prototype of a teaching die for the specialty of precision mechanical design in mechatronic engineering, in order to achieve the skills required in unit two, regarding dies. The methodology used consists of five stages: 1 . Definition of the preliminary conditions. 2. Theoretical calculations for die design. 3. Design, modeling and assembly using computer-aided
\end{abstract}




\section{https://revistainvestigacionacademicasinfrontera.unison.mx/index.php/RDIASF}

Recibido el 28 de junio de 2020. Dictaminado mediante arbitraje favorablemente 18 de diciembre de 2020.

software (CAD) of the parts that make up the die. 4. Validation with simulation of finite element analysis (AEF). 5. Manufacture of parts and physical assembly of the die. A functional prototype was obtained with which the teacher and student can perform calculations, designs and CAD models, AEF analysis of the static and fatigue type, manufacture of rapid prototypes using 3D printing, the identification of the parts that make up a die and their functioning. The advantage of this prototype, compared to metal diecutting machines, is its low cost of production and manufacturing, it does not require expensive and specialized machinery for manufacturing, specific designs can be made by the students and its subsequent manufacture within the laboratories of the Technological Institute of Hermosillo.

\section{Key words: Prototype, didactic, die}

\section{Resumen}

El objetivo de esta investigación es manufacturar un prototipo de troquel didáctico para la materia de especialidad de diseño mecánico de precisión de ingeniería mecatrónica, para poder alcanzar las competencias requeridas en la unidad dos, referente a troqueles. La metodología empleada consta de cinco etapas: 1. Definición de las condiciones preliminares. 2. Cálculos teóricos para el diseño del troquel. 3. Diseño, modelado y ensamble mediante software asistido por computadora (CAD), de las piezas que integran el troquel. 4. Validación con simulación de análisis de elementos finitos (AEF). 5. Manufactura de piezas y ensamble físico del troquel. Se obtuvo un prototipo funcional con el que el docente y el alumno pueden realizar cálculos, diseños y modelos CAD, análisis AEF del tipo estático y de fatiga, manufactura de prototipos rápidos mediante impresión $3 \mathrm{D}$, la identificación de las partes que conforman un troquel y su funcionamiento. La ventaja de este prototipo, frente a máquinas de troquelado metálicas, es su bajo costo de producción y fabricación, no se requiere maquinaria costosa y especializada para la manufactura, se pueden realizar diseños específicos por parte de los alumnos y su posterior fabricación dentro de los laboratorios del Instituto Tecnológico de Hermosillo.

\section{Palabras clave: Prototipo, didáctico, troquel}




\section{https://revistainvestigacionacademicasinf rontera.unison.mx/index.php/RDIASF}

Recibido el 28 de junio de 2020. Dictaminado mediante arbitraje favorablemente 18 de diciembre de 2020.

\section{Introduction}

The traditional teaching of mechatronic engineering in any of its branches requires the development of theoretical research work, subsequently validated by field or laboratory practice (Rodríguez-Cepeda, 2016). Nonetheless, computer-tech development makes tools such as educational software, internet pages, content management platforms, etc., available to teaching-learning management, which allows the simulation of processes and phenomena (Tangarife-Chalarca, 2013; Solano-Vellanueva, Casas-Díaz \& Guevara-Bolaños, 2015; Gutiérrez-Rodríguez, 2018), and that has permeated the classroom environment, allowing the appearance of specific didactic material for the teaching of scientific and technological concepts (Niño \& Fernández, 2019). With the combination of theory, simulation, and practice, it is possible to understand phenomena that may be poorly understood only from one of these three perspectives, which improves the meaningful learning of the student.

The mechatronics engineering curriculum of the Technological Institute of Hermosillo requires the use of laboratories for specific subjects, mainly in the early semesters, such as in the learning of physics, chemistry, electronics, and mechanics, to name a few. However, laboratories for learning specialty subjects are limited to the acquisition of specialized equipment, due to specialty subjects are valid for a maximum of three years within the system (Tecnológico Nacional de México, 2015), For this reason, the professorship is carried out theoretically, combining specialized simulators in some cases, leaving aside practical work in the field or laboratory.

It has been observed that the development of prototypes for engineering learning can be a critical tool, analogous to field practice or the execution of laboratory practices (Sierra, Adame, Pantoja \& Valvantín, 2019; Chávez, Villaseñor \& Bracamontes, 2019; Cabrera, Sánchez, Medina \& Arias, 2017). For the development of these prototypes, additive manufacturing (3D printing) is used, an emerging technology that makes it possible to manufacture parts from the superposition of layers of different materials, taking as a reference a previous design, without molds, directly from a virtual model (Basco, Beliz, Coatz \& Garnero, 2018).

Currently, the subject of "precision mechanical design" has within its thematic content in unit 2, the topic of dies, where four important points are specified to achieve the competencies of this unit: 
Año 13.

Núm. 33
Revista de Investigación

Académica sin Frontera

ISSN: 2007-8870

\section{https://revistainvestigacionacademicasinfrontera.unison.mx/index.php/RDIASF}

Recibido el 28 de junio de 2020. Dictaminado mediante arbitraje favorablemente 18 de diciembre de 2020.

1. Punch and die calculations.

2. Computer-aided design (CAD) and modeling of the parts that make up a die.

3. Static validation through finite element analysis (FEA) with specialized software.

4. Laboratory practice to identify the parts and operation of dies.

Of the four points mentioned, the competencies achieved are limited to points 1, 2, and 3, because there are no dies in any laboratory within the Institute to carry out practices.

The objective of this research is to manufacture a didactic die prototype for the specialty subject of "precision mechanical design" of mechatronics engineering, through the integration of theoretical calculations, design, and computational modeling, validation with finite element analysis simulation (FEA) and 3D printing manufacturing; materials and equipment available in the mechatronics engineering laboratory of the Technological Institute of Hermosillo.

This research is intended to be a tool to achieve the specific competencies of unit 2 of the subject of precision mechanical design, through rapid prototyping with 3D printing.

This research is integrated from a methodological development, the integration of results and conclusions. The methodological development consists of 5 stages: preliminary conditions, calculation, modeling, validation, and manufacture of the didactic die.

The results show the theoretical calculations, the models designed in Solidworks software, the results of static and fatigue analysis in Solidworks Simulation, and the physical assembly of the die. 
Año 13.

Núm. 33
Académica sin Frontera

ISSN: 2007-8870

\section{https://revistainvestigacionacademicasinfrontera.unison.mx/index.php/RDIASF}

Recibido el 28 de junio de 2020. Dictaminado mediante arbitraje favorablemente 18 de diciembre de 2020.

\section{METHODOLOGICAL DEVELOPMENT}

The methodological development used for this research is carried out in five main stages: preliminary conditions, calculation, modeling, validation, and manufacturing of the didactic die. The methodological procedure is shown in Figure 1 and is described below.

Stage I. Preliminary conditions.

1. Selection of the piece to die. The part is chosen to define its geometries and internal/external contours.

2. Selection of material. The material whose mechanical specifications meet the function of the part is selected.

\section{Stage II. Calculations.}

1. Calculation of loads for the stamping process. The calculations presented in this section are based on the Archuleta methodology used (2015). It is based on the calculation of six main loads: shear load $\left(F_{c}\right)$, internal geometry punching load $\left(\mathrm{F}_{\text {int }}\right)$ and external $\left(\mathrm{F}_{\text {ext }}\right)$, total load $\left(\mathrm{F}_{\mathrm{T}}\right)$ and extraction load considering a $10 \%$ shear load $\left(\mathrm{F}_{\mathrm{E}}\right)$, total load with press efficiency.

$$
\begin{aligned}
& \mathrm{F}_{\mathrm{c}}=\mathrm{F}_{\text {int }}=\mathrm{F}_{\text {ext }}=\tau \mathrm{tL} \\
& \mathrm{F}_{\mathrm{T}}=\mathrm{F}_{\text {int }}+\mathrm{F}_{\text {ext }} \\
& \mathrm{F}_{\mathrm{E}}=0.1 \mathrm{~F}_{\mathrm{T}} \\
& \mathrm{F}_{\mathrm{EFI}}=\left(\mathrm{F}_{\mathrm{T}}+\mathrm{F}_{\text {ext }}\right) / \% \text { Efficiency }
\end{aligned}
$$

Where $\tau$ is the resistance of the material at cutting, $t$ is the thickness of the material and $L$ the length of the cutting edge. 
Año 13.

Núm. 33
Académica sin Frontera

ISSN: 2007-8870

\section{https://revistainvestigacionacademicasinfrontera.unison.mx/index.php/RDIASF}

Recibido el 28 de junio de 2020. Dictaminado mediante arbitraje favorablemente 18 de diciembre de 2020.

2. Calculations for matrix. To determine the dimensions of the matrix, the proportions of the standardized values in table 1 are used, where the values of $\mathrm{B}$ and $\mathrm{C}$ can be obtained, from the conditions of $\mathrm{A}$. The following equations established by (Boljanovic \& Paquin, 2006) are used to determine the length (L) and width $(\mathrm{H})$ of the matrix:

$$
\begin{aligned}
& \mathrm{L}=\text { Cavity length }+2 \mathrm{C} \\
& \mathrm{H}=\text { Cavity width }+2 \mathrm{C}
\end{aligned}
$$


Año 13.

Núm. 33
Académica sin Frontera

ISSN: 2007-8870

\section{https://revistainvestigacionacademicasinfrontera.unison.mx/index.php/RDIASF}

Recibido el 28 de junio de 2020. Dictaminado mediante arbitraje favorablemente 18 de diciembre de 2020.

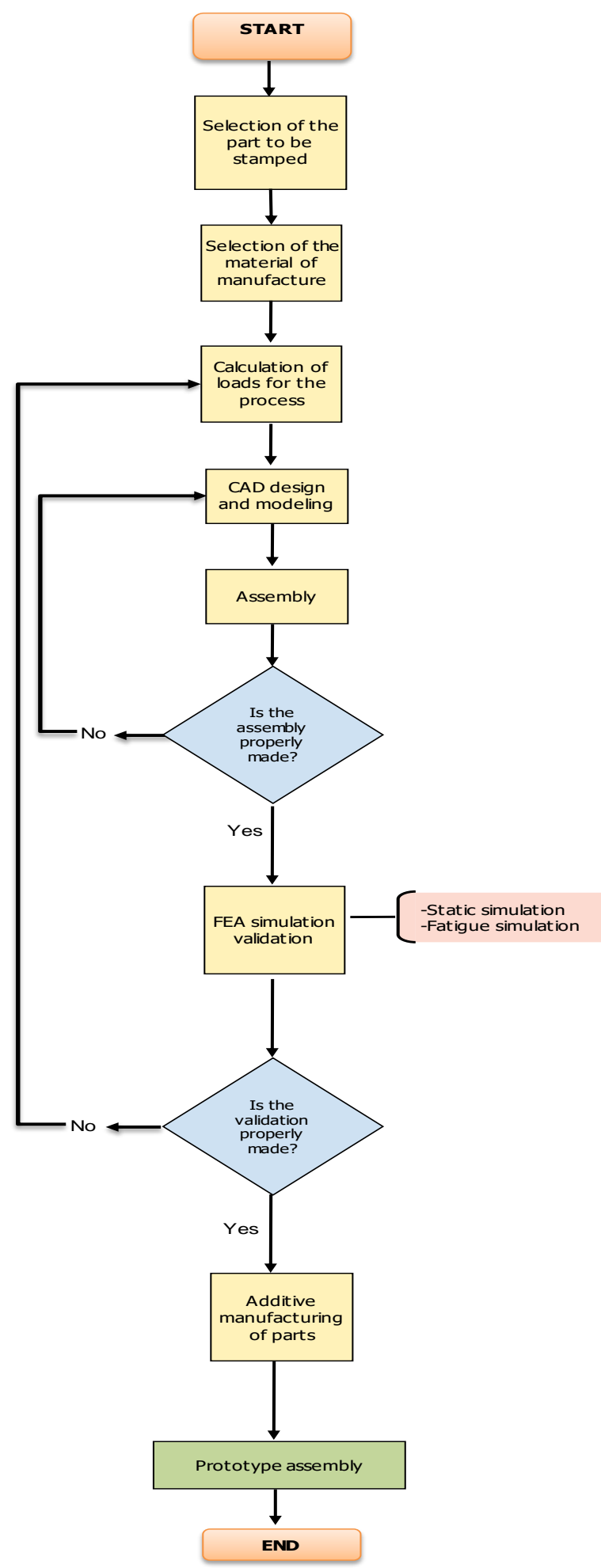

Figure 1 Methodological process. The authors. 
Año 13.

Núm. 33
Revista de Investigación

Académica sin Frontera

ISSN: 2007-8870

\section{https://revistainvestigacionacademicasinfrontera.unison.mx/index.php/RDIASF}

Recibido el 28 de junio de 2020. Dictaminado mediante arbitraje favorablemente 18 de diciembre de 2020.

In Archuleta (2015), it is established that, within the stamping processes, the matrix presents tear derived from the impacts to which it is exposed, for which it is considered to extend its useful life $\mathrm{Vu})$, through the following equation:

$$
\mathrm{V}_{\mathrm{u}}=3 \mathrm{t}
$$

The escape angle $(\alpha)$ is located immediately after $V_{u}$ established in the design and allows the stamped parts to be released effectively, without presenting excessive clogging or friction within the matrix released effectively (Almeida, 2017). Ginjaume \& Torre (2005) propose to use an $\alpha$ of 1 to $3^{\circ}$, and up to $6^{\circ}$ in low production matrix processes. Archuleta (2015), proposes an $\alpha=3^{\circ}$.

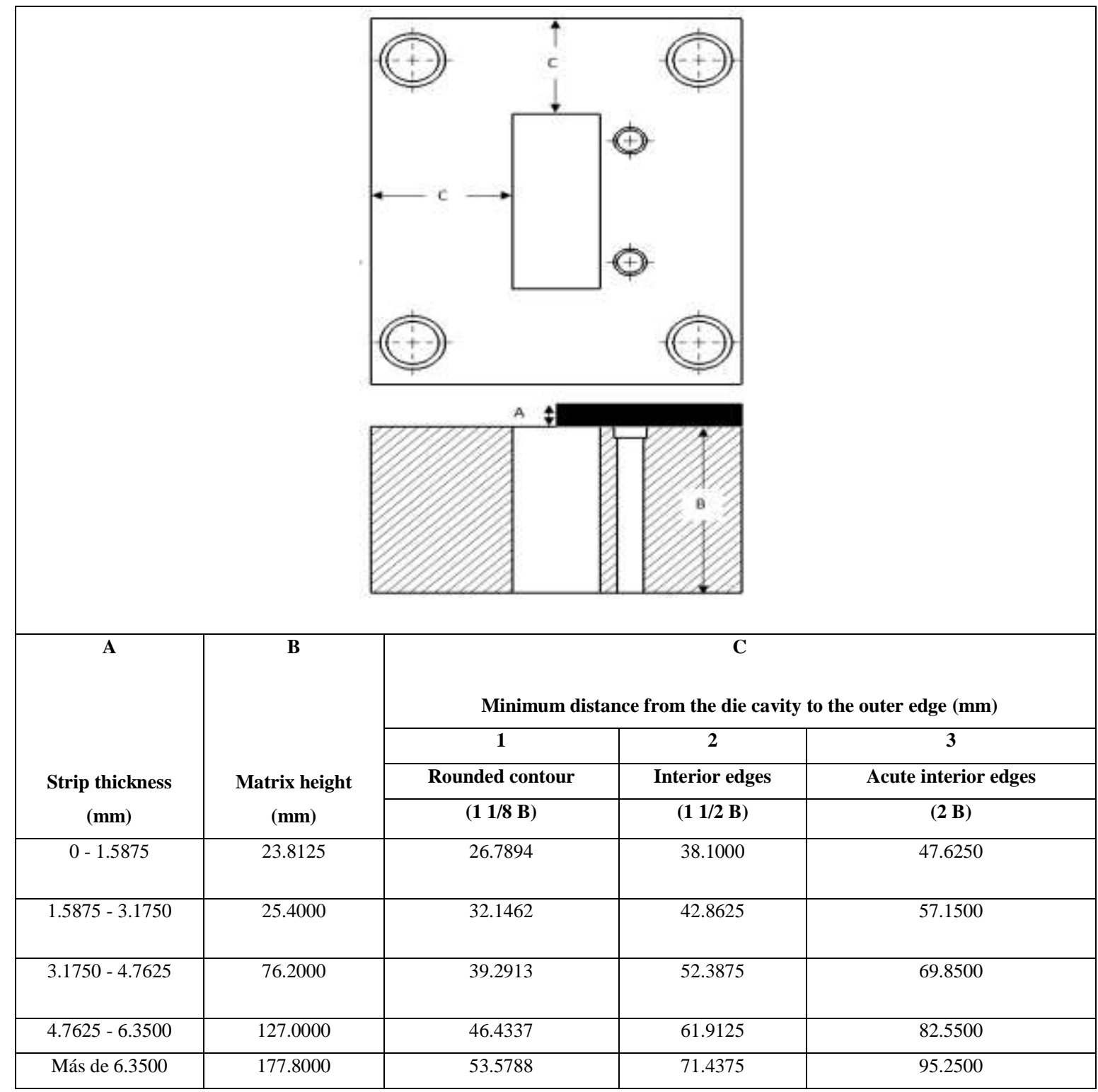

Table 1. Dimensional properties of the matrix. Adapted from (Boljanovic \& Paquin, 2006). 
Año 13.

Núm. 33
Académica sin Frontera

ISSN: 2007-8870

\section{https://revistainvestigacionacademicasinfrontera.unison.mx/index.php/RDIASF}

Recibido el 28 de junio de 2020. Dictaminado mediante arbitraje favorablemente 18 de diciembre de 2020.

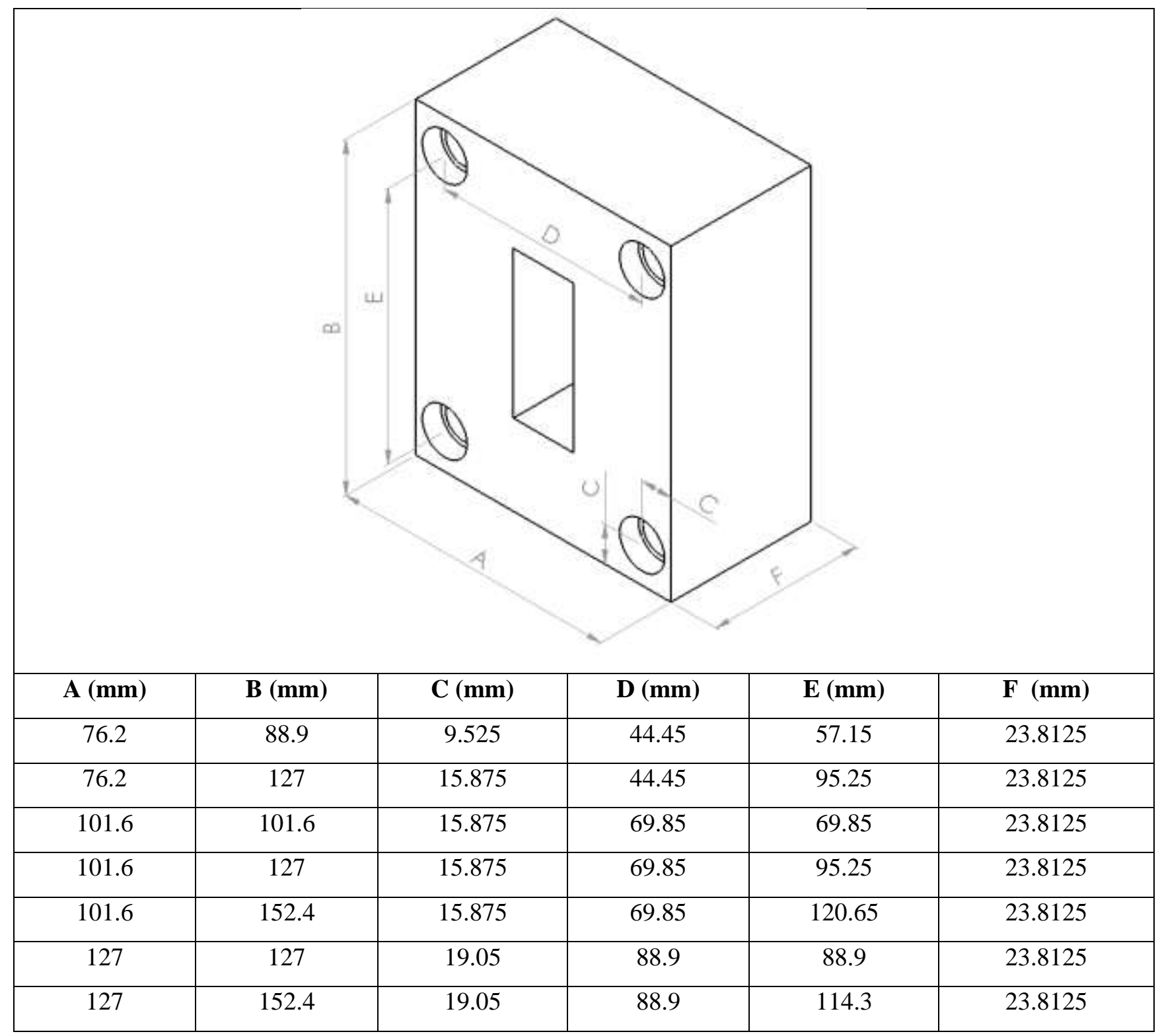

Tabla 2 Location of clamping holes. Adapted from (Boljanovic \& Paquin, 2006).

3. Calculations for punch. The calculation that is made to the punch is about the clearance (CL) that it must have concerning the matrix. The gap is the minimum separation that exists between both elements, mainly to avoid friction (Aguayo, 2014). To determine the value of CL the following equation is used:

$$
\mathrm{C}_{\mathrm{L}}=\mathrm{t} / \mathrm{K}
$$


Año 13.

Núm. 33
Académica sin Frontera

ISSN: 2007-8870

\section{https://revistainvestigacionacademicasinfrontera.unison.mx/index.php/RDIASF}

Recibido el 28 de junio de 2020. Dictaminado mediante arbitraje favorablemente 18 de diciembre de 2020.

Where $\mathrm{K}$ is the material constant to calculate the gap.

Stage III. CAD design, modeling and assembly.

Solidworks software is used for the design and CAD modeling of the parts, based on the methodology used by Planchard (2020) and Tran (2020), through the use of sketching techniques and basic and advanced operations for modeling. For assembly purposes, the methodology of Almattar (2019) was used, based on the configuration of the assembly complement of the Solidworks software. For twodimensional design, basic sketch operations were used within Solidworks software. These operations include marking lines, circles, points, polygons, ellipses, grooves, arcs, chamfers and fillets, circular and linear patterns, symmetry, as well as the smart dimension feature and the use of planes. For threedimensional design, modeling features were used within Solidworks software. These operations include using planes, faces, and axes, extrude, boss/base revolution, swept base boss, loft, extrude cut, hole wizard, solid fillets and chamfers, circular and linear pattern on solids, solid symmetry, among other. For component assembly, the assembly option was used within the Solidworks software. This software library allows to mechanically join all the modeled components and allows kinematic movements of the unit parts, to predict incorrect kinematics or possible design errors, especially regarding the dimensional considerations of the components, which must be designed with a precision approach to avoid manufacturing problems.

\section{Stage IV. FEA validation.}

The validation consists of the static and fatigue analysis of the punch, the tool that performs the cutting work and that is susceptible to damage from plastic deformation or imminent fracture.

1. Static analysis. Static analyzes allow the calculation of displacements, strains, stresses, and reaction forces under applied loads (Estrada et al, 2017). The analysis is carried out with Solidworks Simulation, based on the methodology proposed by Solidworks (2018 a). The methodology to carry out the static analysis in software is presented in figure 2 . The methodological calculation process is shown in figure 3. 
Año 13.

Núm. 33
Revista de Investigación

Académica sin Frontera

ISSN: 2007-8870

\section{https://revistainvestigacionacademicasinfrontera.unison.mx/index.php/RDIASF}

Recibido el 28 de junio de 2020. Dictaminado mediante arbitraje favorablemente 18 de diciembre de 2020.

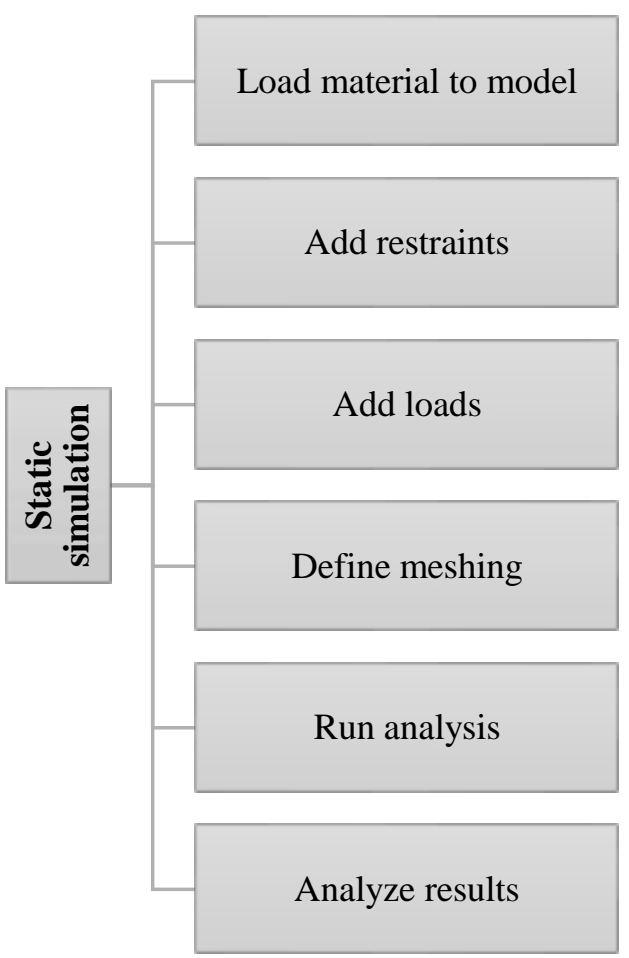

Figure 2 Methodological process to perform static analysis with Solidworks. Solidworks $(2018 \mathrm{a})$.

2. Fatigue analysis. In materials engineering, fatigue is the weakening of a material caused by cyclical loading that results in progressive and localized structural damage and the growth of cracks (Murakami \& Miller, 2005). In Solidworks (2018 e), it is established that for each cycle of voltage fluctuation it weakens the object up to a certain point, and therefore, after several cycles, the object is so weak that it fails. The methodology to carry out the fatigue analysis in software is presented in figure 4 . The calculation methodology used by the software is based on the theory of cumulative damage, this theory assumes that the stress cycle with alternating stress above the limit resistance causes measurable permanent damage, furthermore, it assumes that the total damage caused by several stress cycles is equal to the sum of the damage caused by individual stress cycles (Solidworks, $2018 \mathrm{~g}$ ). The equation for calculating fatigue by the software is the one established by Miner's Rule. 
Año 13.

Núm. 33
Académica sin Frontera

ISSN: 2007-8870

\section{https://revistainvestigacionacademicasinfrontera.unison.mx/index.php/RDIASF}

Recibido el 28 de junio de 2020. Dictaminado mediante arbitraje favorablemente 18 de diciembre de 2020.
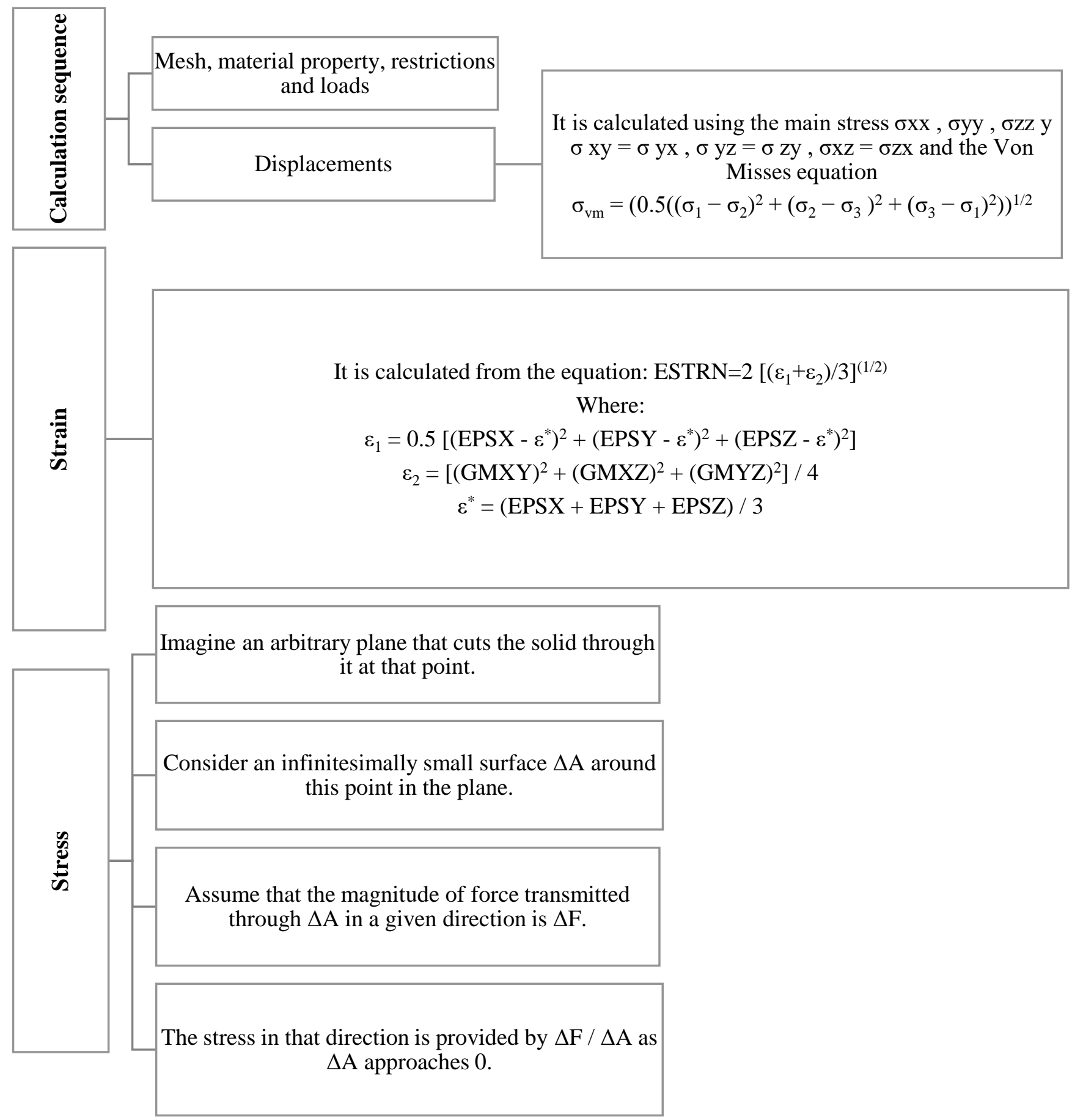

Figure 3 Methodological calculation process for Solidworks software in static analysis. Adapted from (Solidworks, 2018 b), (Solidworks, 2018 c) and (Solidworks, $2018 \mathrm{~d}$ ). 
Año 13.

Núm. 33
Revista de Investigación

Académica sin Frontera

ISSN: 2007-8870

\section{https://revistainvestigacionacademicasinfrontera.unison.mx/index.php/RDIASF}

Recibido el 28 de junio de 2020. Dictaminado mediante arbitraje favorablemente 18 de diciembre de 2020.

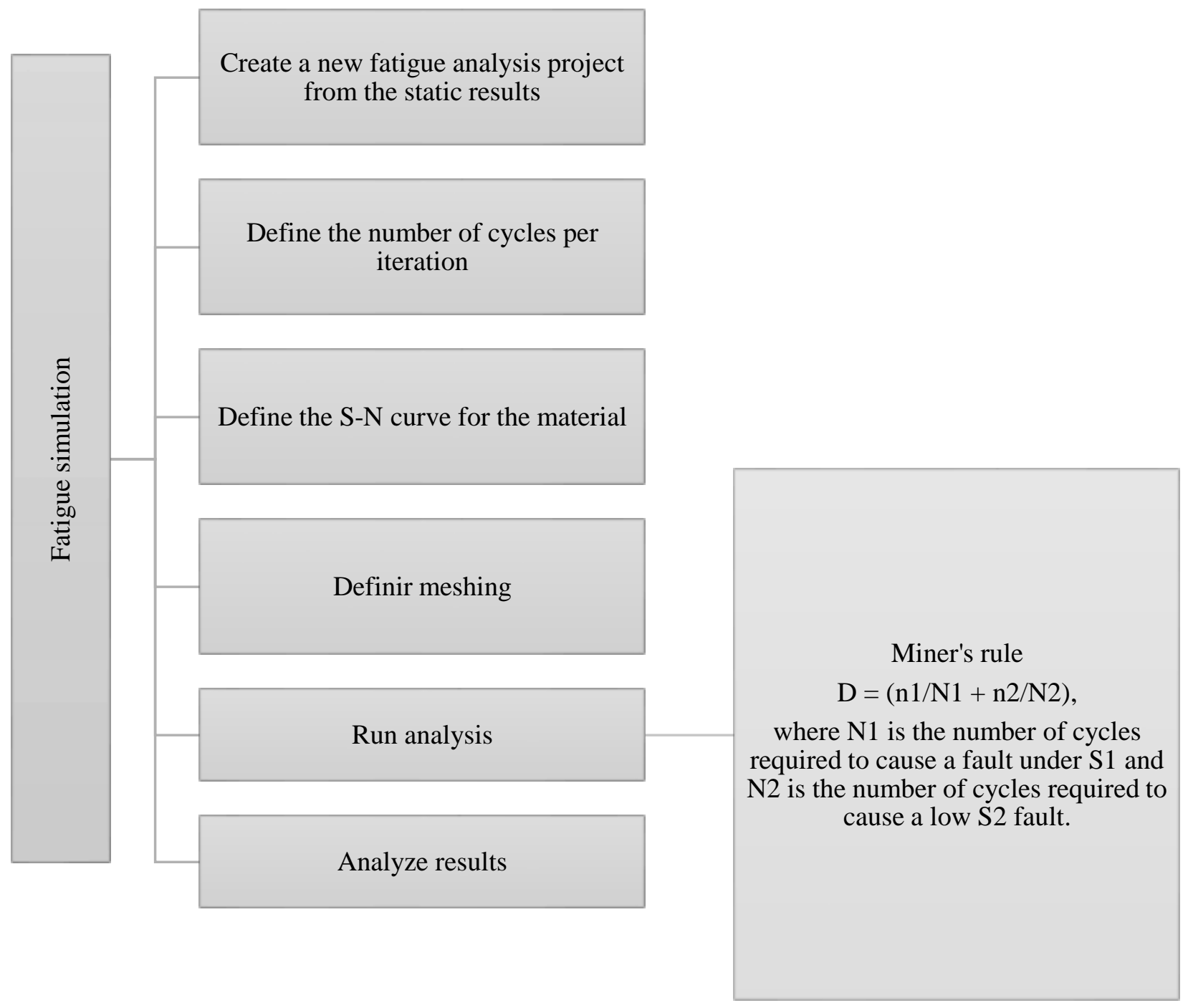

Figure 4 Methodological calculation process of Solidworks software in fatigue analysis. Adapted from (Solidworks, 2018f).

Stage V. Parts manufacturing.

The methodology of the manufacture of the components was based on the following steps:

1. Convert the models made to ".stl" format using Solidworks.

2. Import the models in ".stl" format to the Ultimaker Cura program.

3. Select the material for manufacturing. 
Año 13.

Núm. 33
Académica sin Frontera

ISSN: 2007-8870

\section{https://revistainvestigacionacademicasinfrontera.unison.mx/index.php/RDIASF}

Recibido el 28 de junio de 2020. Dictaminado mediante arbitraje favorablemente 18 de diciembre de 2020.

4. Configure the settings according to the finish for the pieces, as well as the necessary temperature conditions to work with the selected material.

5. Save as GCode file.

6. Print the parts.

\section{RESULTS}

The part shown in Figure 5 was chosen to carry out the punching process.

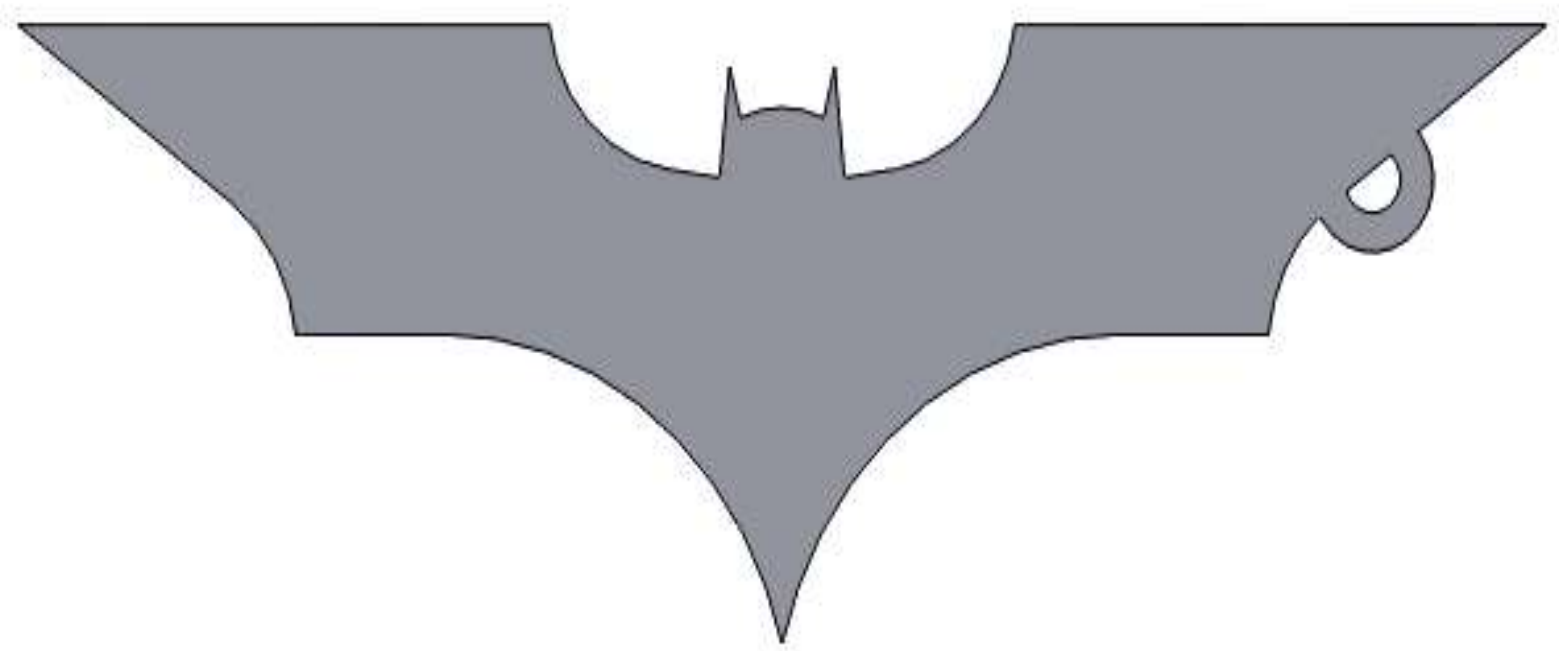

Figure 5 Piece selected for the process and dimensions in $\mathrm{mm}$. The authors.

Stage I: Initial conditions.

As initial conditions, the following were established:Material:

AISI 304 Stainless steel

$\mathrm{t}=$ size $16=1.52 \mathrm{~mm}=0.00152 \mathrm{~m}$

$\tau=549 \mathrm{MPa}=549 \times 10^{6} \mathrm{~N} / \mathrm{m}^{2}$ 
Año 13.

Núm. 33
Revista de Investigación

Académica sin Frontera

ISSN: 2007-8870

\section{https://revistainvestigacionacademicasinf rontera.unison.mx/index.php/RDIASF}

Recibido el 28 de junio de 2020. Dictaminado mediante arbitraje favorablemente 18 de diciembre de 2020.

Using Solidworks Smart Dimension Tool, the outside perimeter of the part was determined (see Figure 6), having an external perimeter length of $229.2 \mathrm{~mm}=0.2292 \mathrm{~m}$. The internal length was $8.94 \mathrm{~mm}=$ $0.00894 \mathrm{~m}$. Part length (cavity length) $=88 \mathrm{~mm}=0.088 \mathrm{~m}$. Part width (cavity width) $=30 \mathrm{~mm}=0.030$ m.

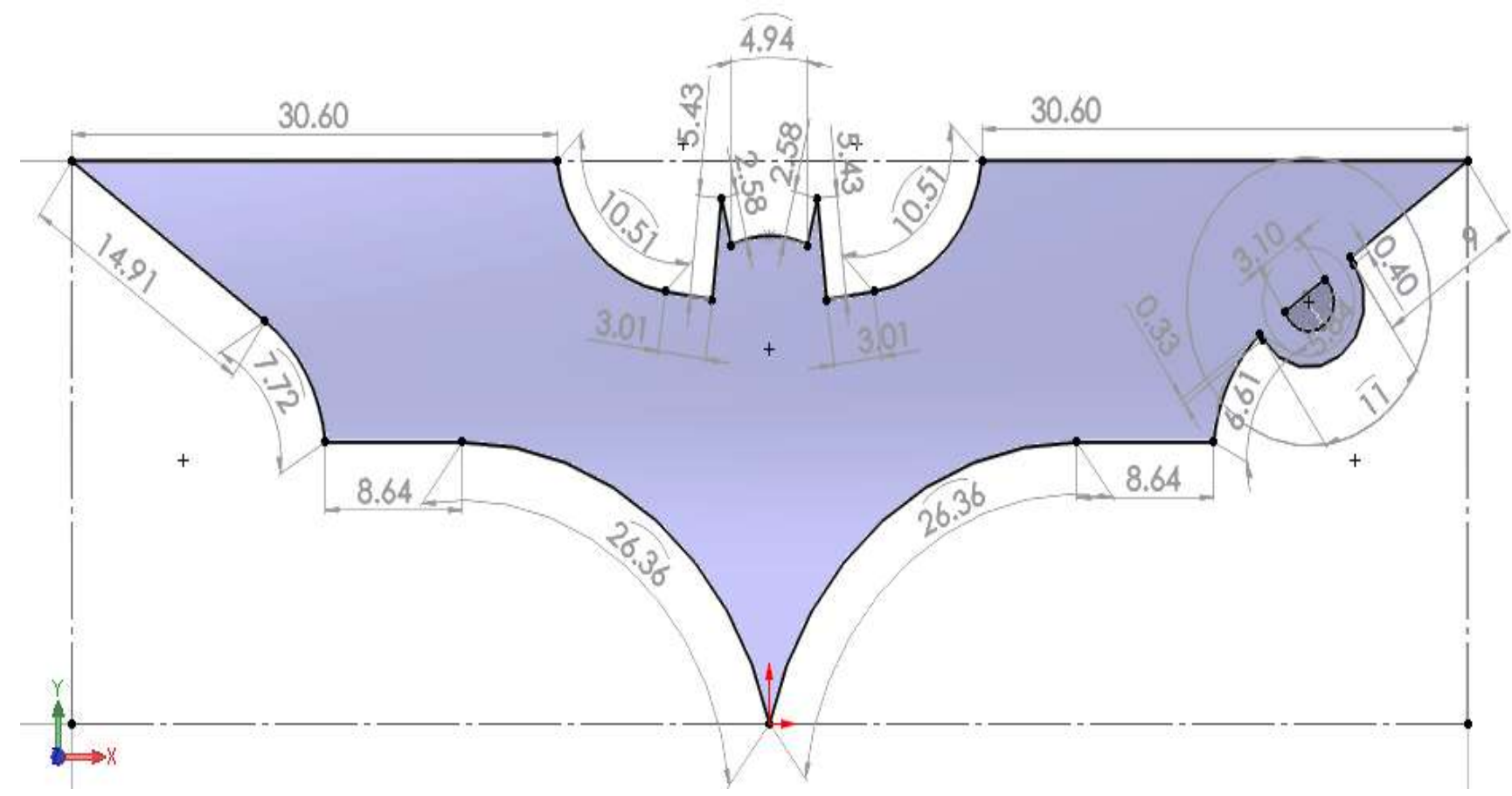

Figure 6 Dimensioned sketch in Solidworks. The authors.

Stage II. Calculations.

1. Calculation of loads for the stamping process. The calculation of the forces from equations 1,2 and 3 was performed.

$$
\begin{aligned}
& \mathrm{F}_{\text {int }}=\left(549 \times 10^{6} \frac{\mathrm{N}}{\mathrm{m}^{2}}\right)(0.00152 \mathrm{~m})(0.00894 \mathrm{~m})=7460.3 \mathrm{~N}=\frac{(7460.3 \mathrm{~N})(1 \mathrm{Ton})}{(1000 \mathrm{~kg})\left(9.81 \frac{\mathrm{m}}{\mathrm{s}^{2}}\right)}=0.76 \text { Ton } \\
& \mathrm{F}_{\text {ext }}=\left(549 \times 10^{6} \frac{\mathrm{N}}{\mathrm{m}^{2}}\right)(0.00152 \mathrm{~m})(0.2292 \mathrm{~m})=191.3 \times 10^{3} \mathrm{~N}=\frac{\left(191.3 \times 10^{3} \mathrm{~N}\right)(1 \mathrm{Ton})}{(1000 \mathrm{~kg})\left(9.81 \frac{\mathrm{m}}{\mathrm{s}^{2}}\right)}=19.5 \text { Ton } \\
& \mathrm{F}_{\mathrm{T}}=19.5 \text { Ton }+0.76 \text { Ton }=20.26 \text { Ton } \\
& \mathrm{F}_{\mathrm{E}}=0.1(20.26 \text { Ton })=2.026 \text { Ton. }
\end{aligned}
$$


Año 13.

Núm. 33
Académica sin Frontera

ISSN: 2007-8870

\section{https://revistainvestigacionacademicasinfrontera.unison.mx/index.php/RDIASF}

Recibido el 28 de junio de 2020. Dictaminado mediante arbitraje favorablemente 18 de diciembre de 2020.

For an efficiency of $83 \%, \mathrm{~F}_{\mathrm{EFI}}$ was estimated from equation 4.

$\mathrm{F}_{\mathrm{EFI}}=\frac{20.26 \mathrm{Ton}+2.06 \mathrm{Ton}}{0.83}=26.8 \mathrm{Ton}$

2. Calculations for matrix. The value of $\mathrm{L}$ and $\mathrm{H}$ was calculated with equations 5 and 6 , and table 1 . For a strip value $\mathrm{t}=1.52 \mathrm{~mm}=0.00152 \mathrm{~m}$ (equivalent to $\mathrm{A}$ in table 1 ), the following values were obtained: $\mathrm{B}=23.8125 \mathrm{~mm}=0.0238125 \mathrm{~m}, \mathrm{C}=38.1 \mathrm{~mm}=0.0381 \mathrm{~m}$, obtained from table 1 , the following were obtained:

$\mathrm{L}=0.088 \mathrm{~m}+2(0.0381 \mathrm{~m})=0.1642 \mathrm{~m}$

$\mathrm{H}=0.030 \mathrm{~m}+2(0.0381 \mathrm{~m})=0.1062 \mathrm{~m}$

The value of the service life was calculated from equation 7 .

$\mathrm{V}_{\mathrm{u}}=3(1.52 \mathrm{~mm})=4.56 \mathrm{~mm}=0.00456 \mathrm{~m}$

3. Calculation for the punch. The clearance value between the die and the punch was calculated with equation 8. This equation is calculated in inches, so the calculation was carried out in these units, and the value was later changed to meters. For the value of $t$, it has an equivalent to 0.0598 inches, the value of $\mathrm{K}$ for stainless steel is 12.5 (Archuleta, 2015).

$\mathrm{C}_{\mathrm{L}}=\frac{0.0598 \mathrm{pulg}}{12.5}=0.0047 \mathrm{In}$

For the clearance by side, divide the value of $\mathrm{C}_{\mathrm{L}}$ over 2 .

$\mathrm{C}_{\mathrm{L}}=\frac{0.0047 \mathrm{In}}{2}=0.00235 \mathrm{In}=5.969 \times 10^{-5} \mathrm{~m}$ 
Año 13.

Núm. 33
Académica sin Frontera

ISSN: 2007-8870

\section{https://revistainvestigacionacademicasinfrontera.unison.mx/index.php/RDIASF}

Recibido el 28 de junio de 2020. Dictaminado mediante arbitraje favorablemente 18 de diciembre de 2020.

Stage III. CAD design, modeling and assembly.

The matrix was designed with the calculations obtained in stage II. Figure 7 shows the dimensions of the width, length and depth of the matrix. From Table 2, the locations of the holes for the tie bars were determined, which can be seen in the design of Figure 8.

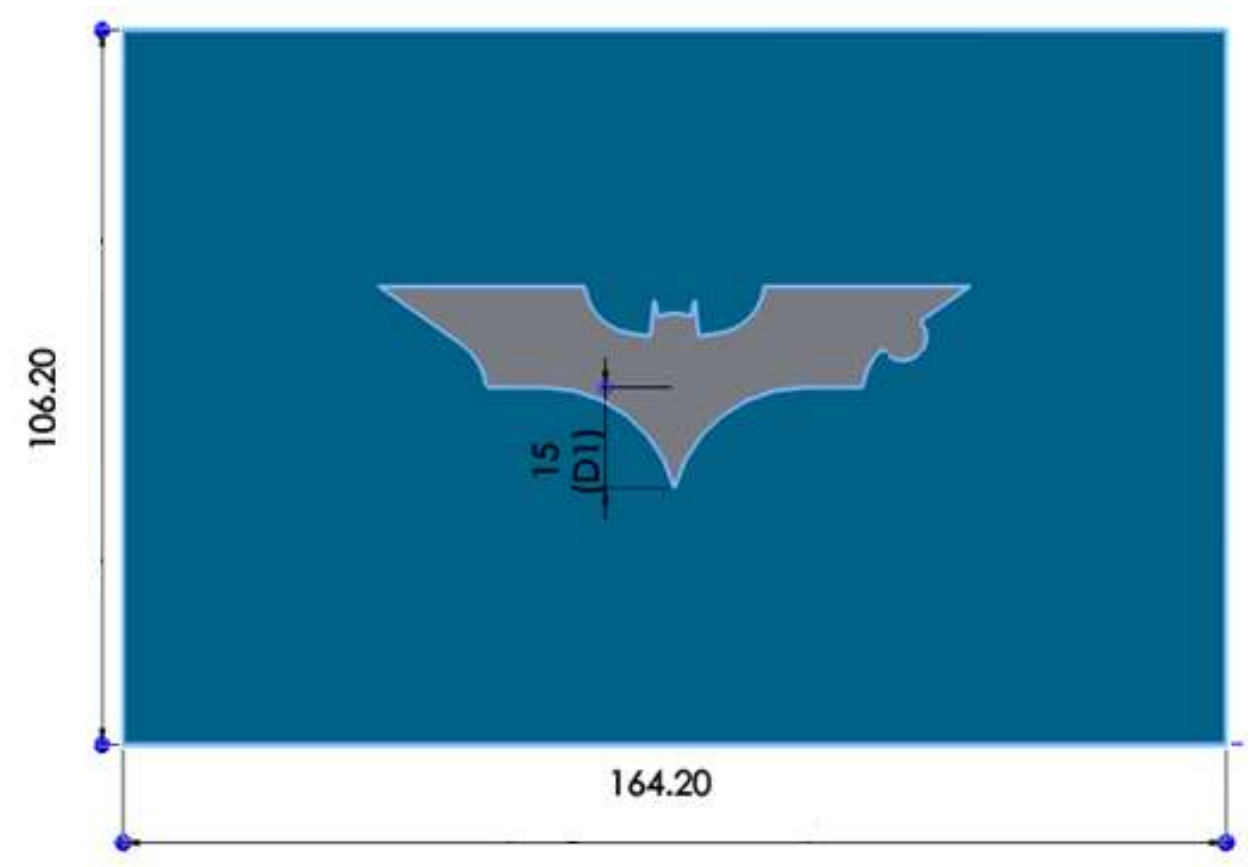

Figure 7 Die dimensioned sketch (in $\mathrm{mm}$ ). The authors. 
Año 13.

Núm. 33
Académica sin Frontera

ISSN: 2007-8870

\section{https://revistainvestigacionacademicasinfrontera.unison.mx/index.php/RDIASF}

Recibido el 28 de junio de 2020. Dictaminado mediante arbitraje favorablemente 18 de diciembre de 2020.

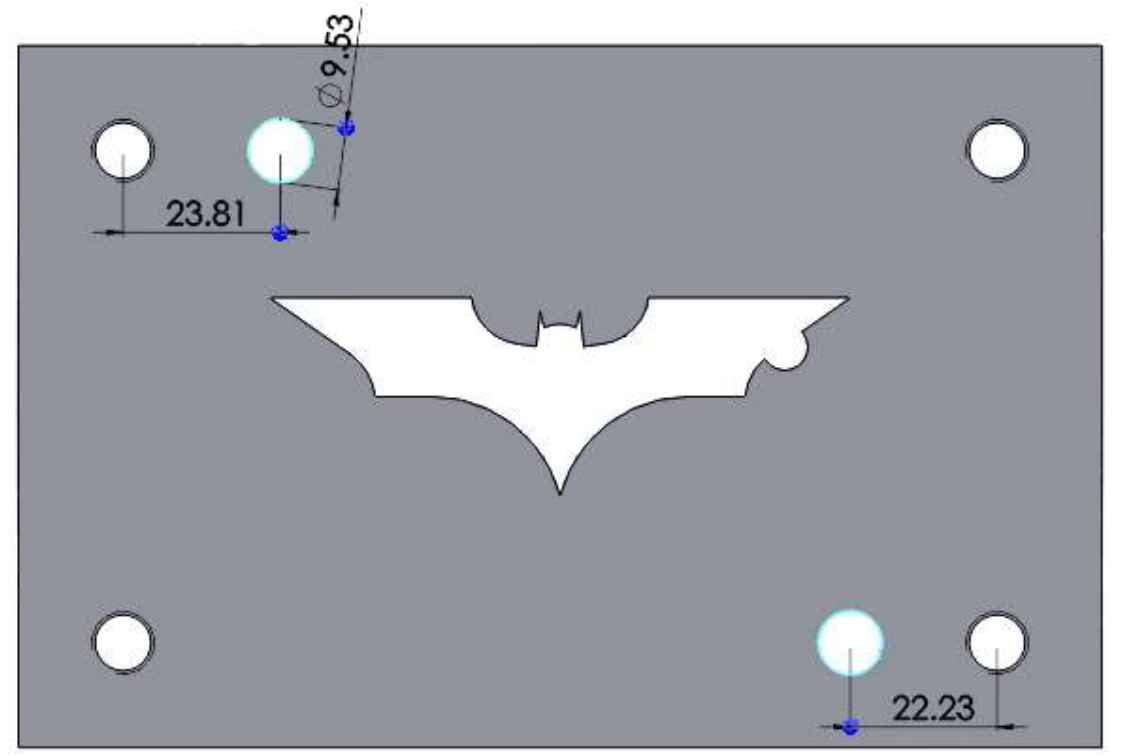

Figure 8 Location of the clamping bars (in $\mathrm{mm}$ ). The authors.

A thickness of $0.00456 \mathrm{~m}=4.56 \mathrm{~mm}$ was added to the width of the matrix, equivalent to the result of $\mathrm{V}_{\mathrm{u}}$, immediately after this thickness, $\alpha=3^{\circ}$ was added to the design. $\mathrm{V}_{\mathrm{u}}$ and $\alpha$ can be seen in figure 9 . The final design of the matrix is shown in isometric in figure 10.

\subsection{6 useful life}

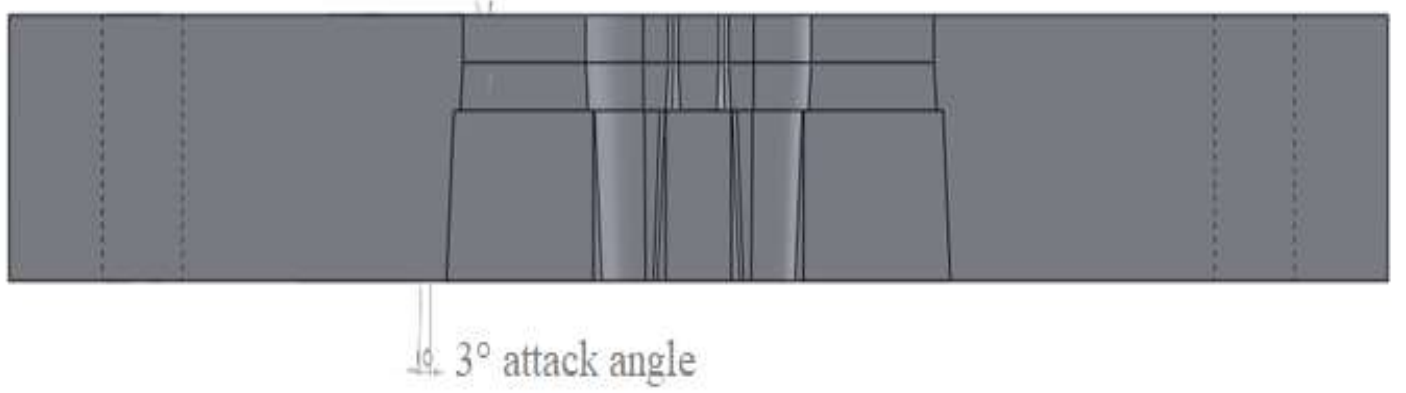

Figure $9 \mathrm{~V}_{\mathrm{u}}(\mathrm{mm})$ and $\alpha$ in matrix. The authors. 
Año 13.

Núm. 33
Revista de Investigación

Académica sin Frontera

ISSN: 2007-8870

\section{https://revistainvestigacionacademicasinfrontera.unison.mx/index.php/RDIASF}

Recibido el 28 de junio de 2020. Dictaminado mediante arbitraje favorablemente 18 de diciembre de 2020.

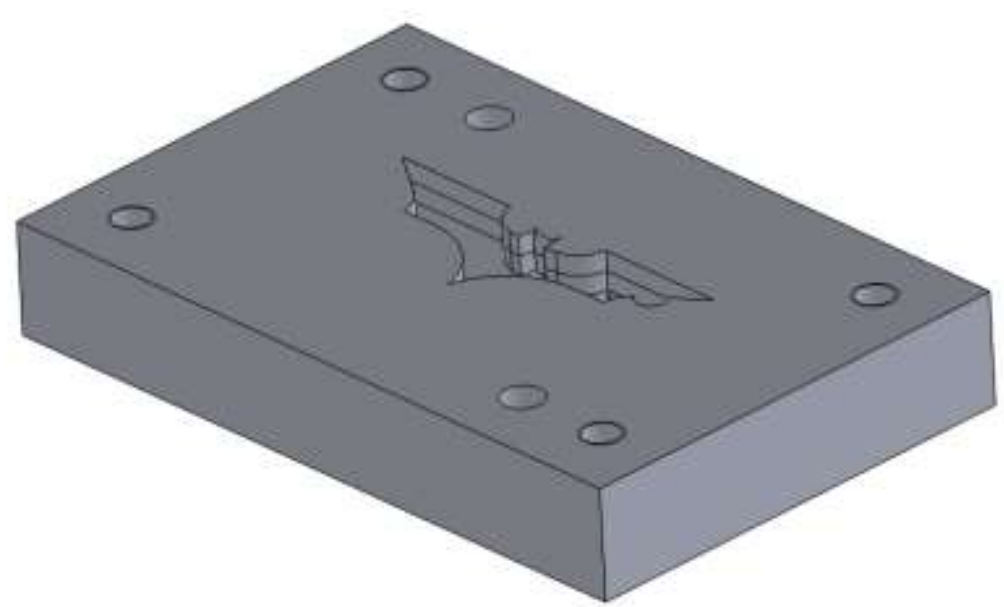

Figure 10 Final design of the matrix. The authors.

For $\mathrm{C}_{\mathrm{L}}$ from the punch, the Solidworks entity offset tool was used to create a sketch contour at a distance of $5.969 \times 10^{-5} \mathrm{~m}=0.056 \mathrm{~mm}$, which can be seen in figure 11 .

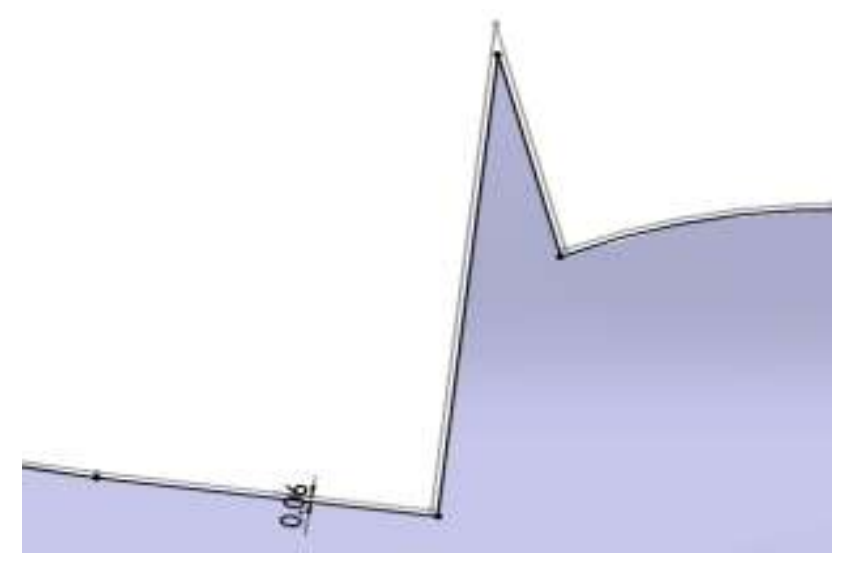

Figure 11 Clearance outline (mm). The authors.

4 holes and 2 registration bolts were added to hold the punch to the punch holder, as shown in figure 12. 
Año 13.

Núm. 33
Académica sin Frontera

ISSN: 2007-8870

\section{https://revistainvestigacionacademicasinfrontera.unison.mx/index.php/RDIASF}

Recibido el 28 de junio de 2020. Dictaminado mediante arbitraje favorablemente 18 de diciembre de 2020.

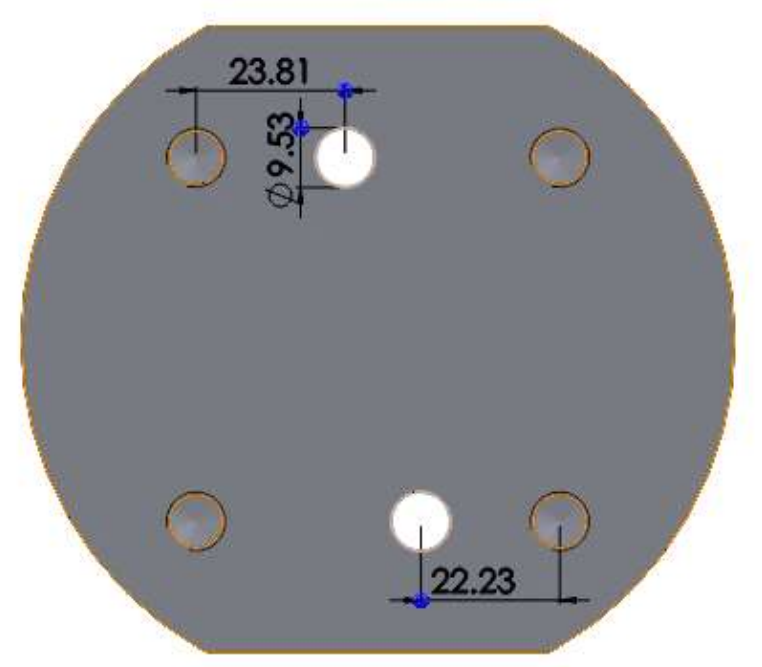

Figure 12 Registration bolts and holes (mm). The authors.

The final design of the punch is seen in figure 13 .

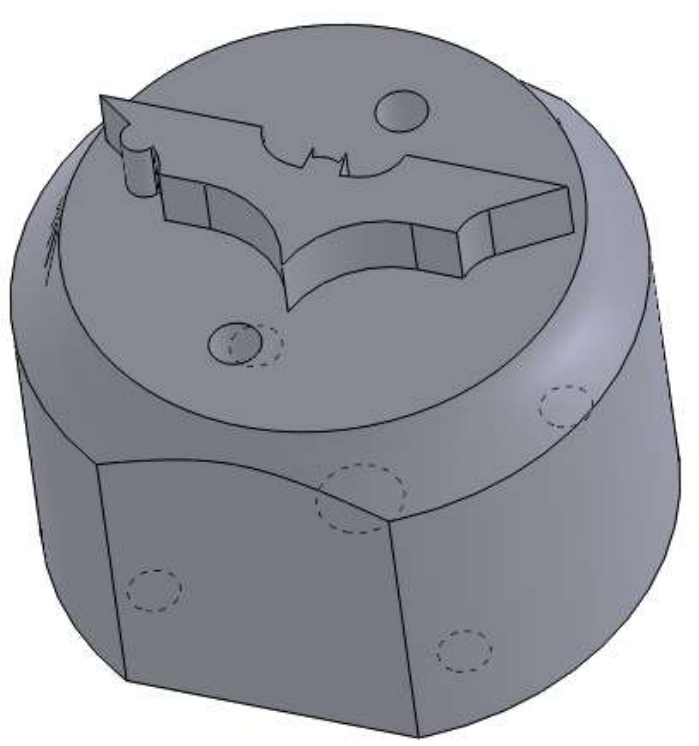

Figure 13 Final design of the punch. The authors.

For the design of the plunger, the same sketch of the die was used and a plate of greater measure than the die was extruded. Next, a cut with a diameter greater than that of the base of the punch was added to 
Año 13.

Núm. 33
Revista de Investigación

Académica sin Frontera

ISSN: 2007-8870

\section{https://revistainvestigacionacademicasinfrontera.unison.mx/index.php/RDIASF}

Recibido el 28 de junio de 2020. Dictaminado mediante arbitraje favorablemente 18 de diciembre de 2020.

avoid a collision between the pieces. Four holes were also added to hold the hold down to the punch holder, the location was determined avoiding the collision of the supports and the hold down with the die. The final design of the clamp is shown in figure 14.

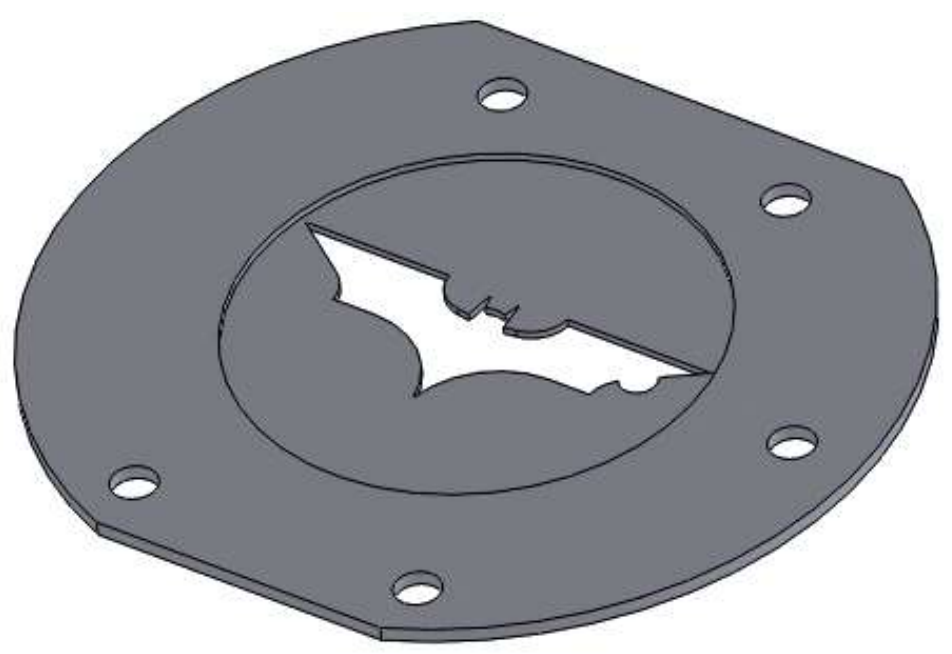

Figure 14 Final design of the plunger. The authors.

For the design of the die holder, a base was used to allow the positioning of the die, in addition to four guide posts, to this base four holes were added and two holes for the registration bolts that were used for the positioning of the die. The holes for the assembly of the guide posts and a central hole were added, which will allow the die-cut piece to fall into a deposit to obtain it. The final design of the die holder can be seen in figure 15 .

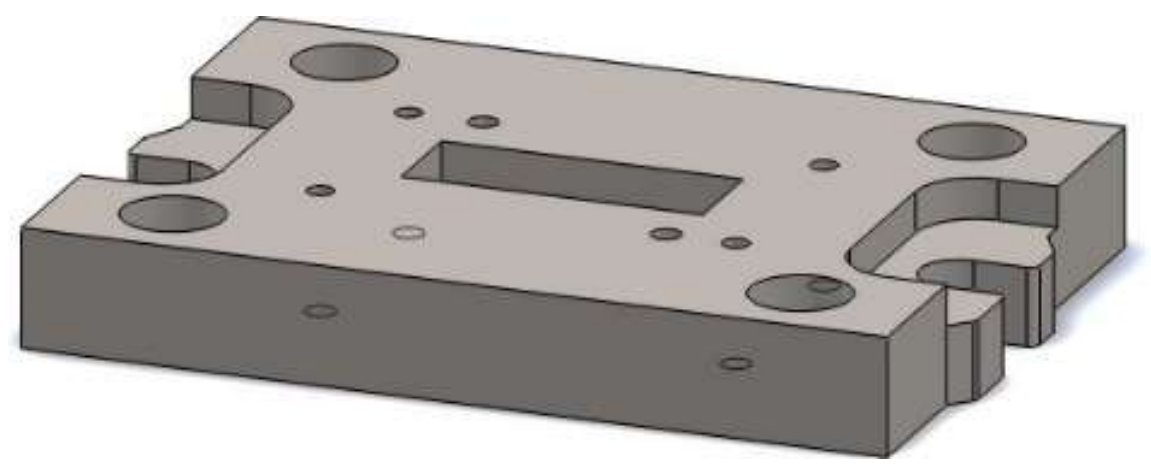

Figure 15 Final design of the matrix holder. The authors. 
Año 13.

Núm. 33
Revista de Investigación

Académica sin Frontera

ISSN: 2007-8870

\section{https://revistainvestigacionacademicasinf rontera.unison.mx/index.php/RDIASF}

Recibido el 28 de junio de 2020. Dictaminado mediante arbitraje favorablemente 18 de diciembre de 2020.

For the design of the punch holder, a base equal to that of the die holder was used, to this base four holes are added with a diameter that would allow the assembly of the bushings found in the guide posts.

Later, the four holes were added to hold the punch, as well as the holes for the registration bolts. The four holes for the screws that will allow the assembly of the plunger were also added. In the central part a hole was added that will allow the union of the press rod with the punch holder. The final design of the punch holder is shown in figure 16.

Once the pieces were designed, the assembly was carried out to check the correct alignment of the pieces. The result of the assembly can be seen in figure 17 .

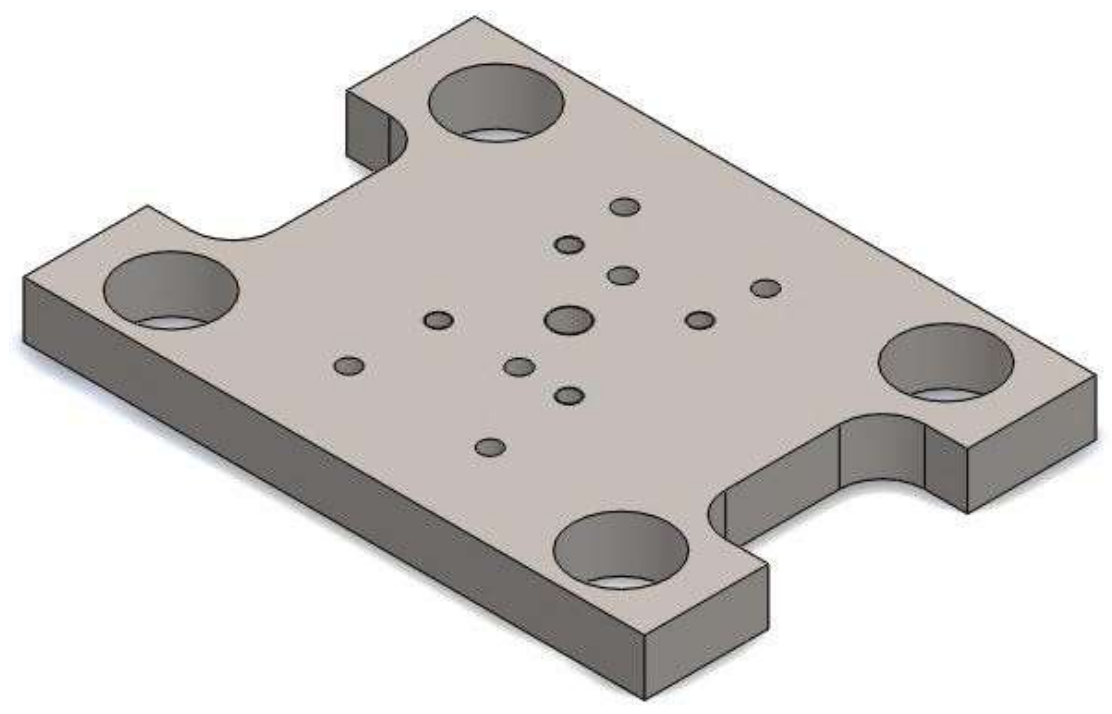

Figure 16 Final design of the punch holder. The authors. 
Año 13.

Núm. 33
Revista de Investigación

Académica sin Frontera

ISSN: 2007-8870

\section{https://revistainvestigacionacademicasinfrontera.unison.mx/index.php/RDIASF}

Recibido el 28 de junio de 2020. Dictaminado mediante arbitraje favorablemente 18 de diciembre de 2020.

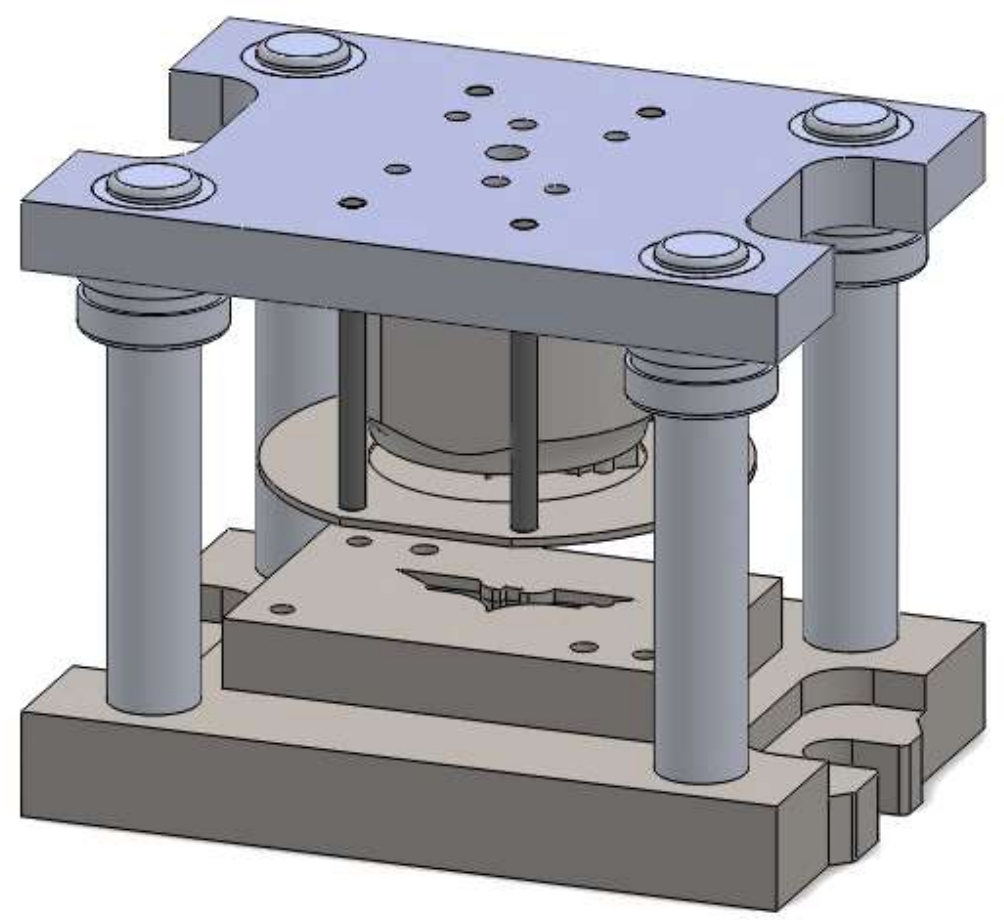

Figure 17 Die assembly. The authors.

Stage IV. FEA validation.

The validation was performed at the punch, through static and fatigue analysis using Solidworks Simulation.

For the simulation, the molded part of the punch was used, a static study was created and the properties of the AISI 304 steel material from the Solidworks material library were used (see figure 18). 
Año 13.

Revista de Investigación

Núm 33

Académica sin Frontera

ISSN: 2007-8870

\section{https://revistainvestigacionacademicasinfrontera.unison.mx/index.php/RDIASF}

Recibido el 28 de junio de 2020. Dictaminado mediante arbitraje favorablemente 18 de diciembre de 2020.
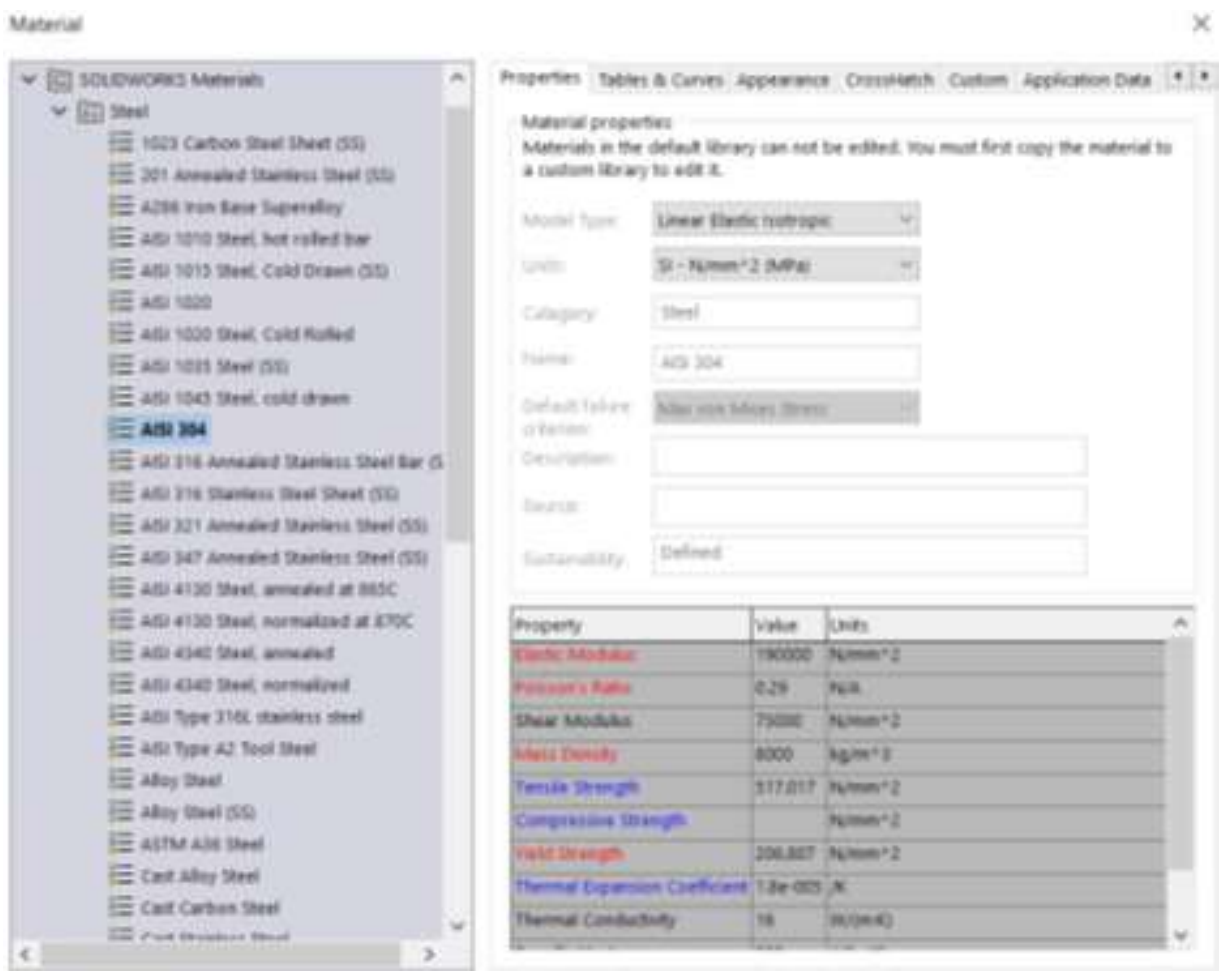

Figure 18 Properties of the AISI 304 material. The authors.

Fixed geometry was subsequently applied to the face shown in figure 19.

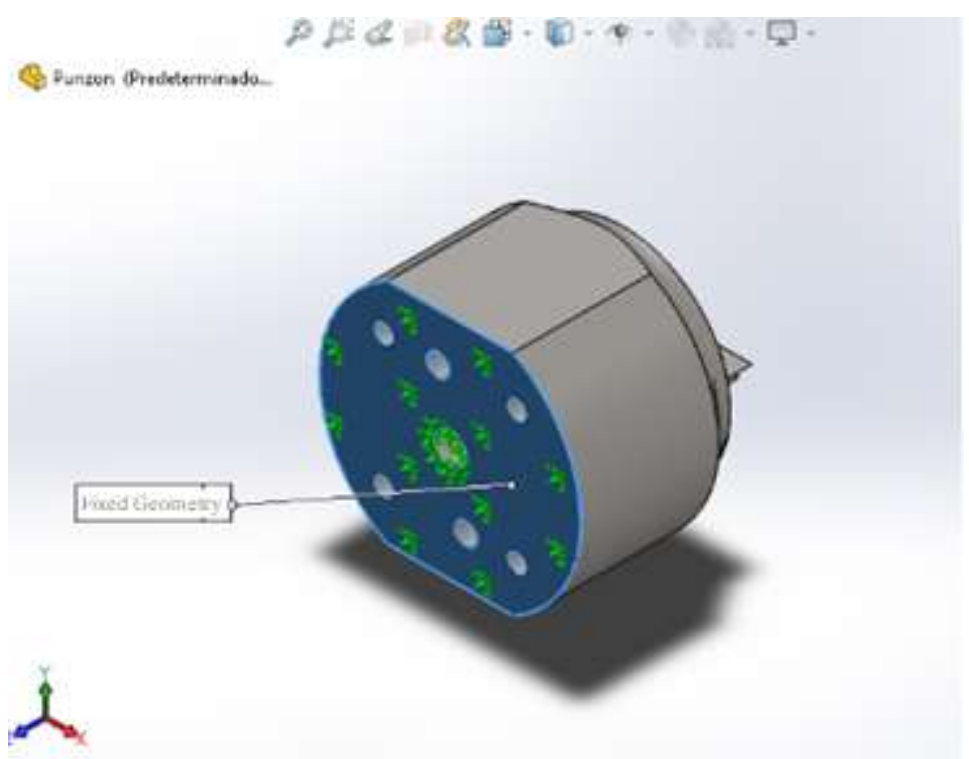

Figure 19 Fixed geometry for punch face. The authors. 
Año 13.

Núm. 33
Revista de Investigación

Académica sin Frontera

ISSN: 2007-8870

\section{https://revistainvestigacionacademicasinfrontera.unison.mx/index.php/RDIASF}

Recibido el 28 de junio de 2020. Dictaminado mediante arbitraje favorablemente 18 de diciembre de 2020.

Next, the load of $263037.5 \mathrm{~N}$ (approximately equivalent to $26.8 \mathrm{Ton}$ ) was added, in a direction perpendicular to the fixed fastening in a state of compression (axial direction to the $\mathrm{z}$ axis), as shown in figure 20 .

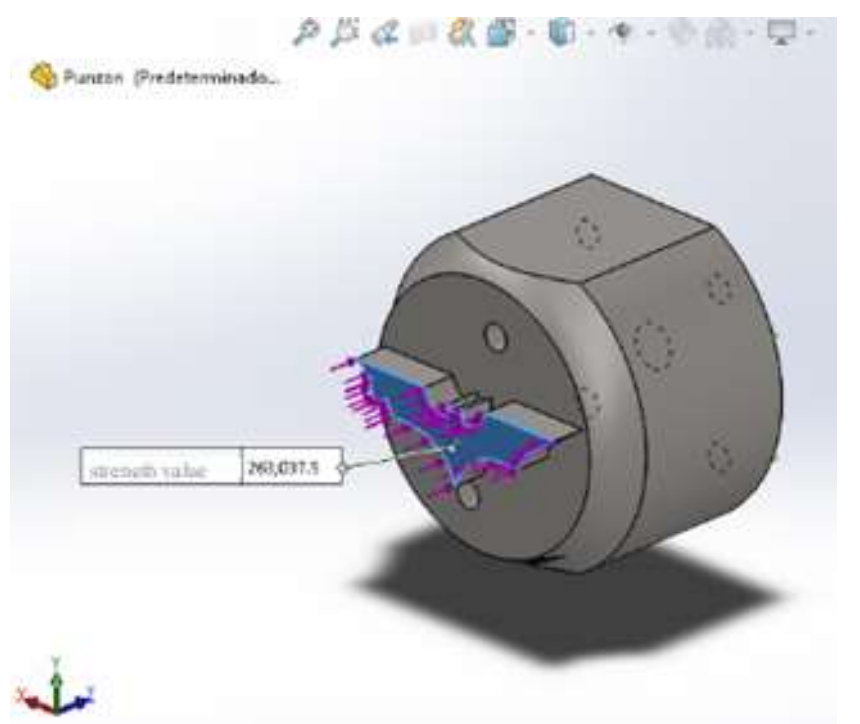

Figure 20 Compressive axial load. The authors.

For the purposes of the fatigue study, 7 events of 1,000 cycles, 10,000 cycles, 100,000 cycles, 1,000,000 cycles, 10,000,000 cycles, 100,000,000 cycles, and 190,000,000 cycles were added respectively. Then the S-N curve is defined with respect to the material, for this case AISI 304 steel (see figure 21).

The meshing for the analysis was carried out with an automatic mesher, generating solid parabolic tetrahedral elements, since they provide better results than linear elements (Solidworks, $2018 \mathrm{~h}$ )

Maximum Von Mises stresses were observed in the separation edges between one step and another in the punch, having a higher concentration in the area where the extrusion of the part to be stamped begins, with a maximum stress value of $5.272 \times 10^{8} \mathrm{~Pa}$, and a minimum stress value of $9.339 \mathrm{x}$ $10^{5} \mathrm{~Pa}$ (see figure 22). 
Año 13.

Núm. 33
Revista de Investigación

Académica sin Frontera

ISSN: 2007-8870

\section{https://revistainvestigacionacademicasinfrontera.unison.mx/index.php/RDIASF}

Recibido el 28 de junio de 2020. Dictaminado mediante arbitraje favorablemente 18 de diciembre de 2020.

\begin{tabular}{|l|l|l|}
\hline Puntos & \multicolumn{1}{|c|}{ N } & \multicolumn{1}{|c|}{ S } \\
\hline 1 & 10 & 3341972859 \\
\hline 2 & 20 & 2437625033 \\
\hline 3 & 50 & 1685232626 \\
\hline 4 & 100 & 1267765149 \\
\hline 5 & 200 & 967566700.7 \\
\hline 6 & 500 & 683432557.6 \\
\hline 7 & 1000 & 536572654.2 \\
\hline 8 & 2000 & 419463988.6 \\
\hline 9 & 5000 & 323118247.2 \\
\hline 10 & 10000 & 272535931.2 \\
\hline 11 & 20000 & 222847635.7 \\
\hline 12 & 50000 & 173019023 \\
\hline 13 & 100000 & 152729167.9 \\
\hline 14 & 200000 & 134271453.5 \\
\hline & & \\
\hline
\end{tabular}

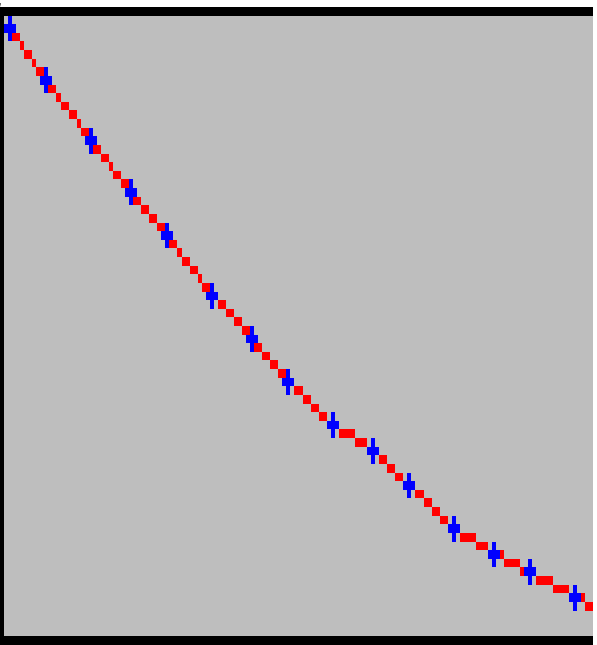

Figure 21 Definition of S-N curve for AISI 304 steel. The authors.
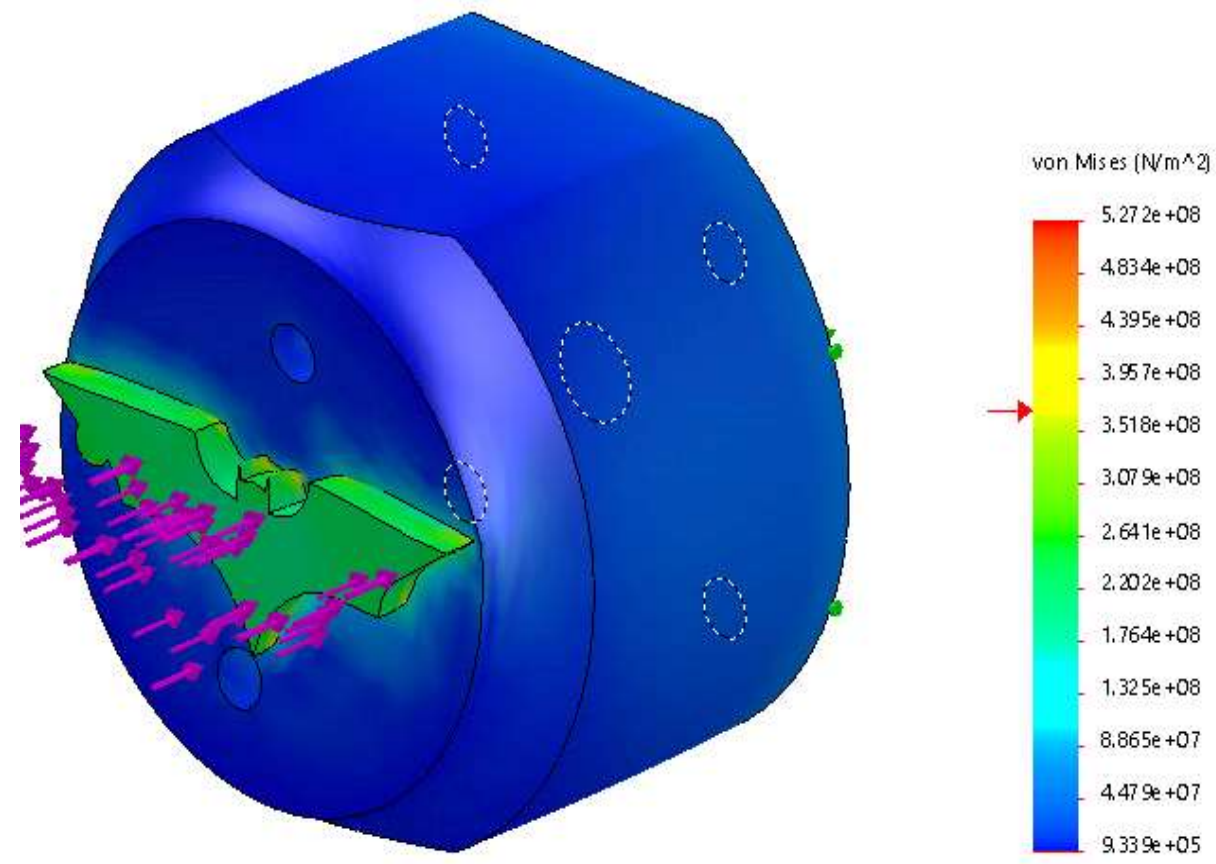

Figure 22 Result of the Von Misses stress. The authors. 
Año 13.

Núm. 33
Revista de Investigación

Académica sin Frontera

ISSN: 2007-8870

\section{https://revistainvestigacionacademicasinfrontera.unison.mx/index.php/RDIASF}

Recibido el 28 de junio de 2020. Dictaminado mediante arbitraje favorablemente 18 de diciembre de 2020.

The piece suffered a maximum displacement in the cross-sectional area of the piece to be stamped, equivalent to $4.153 \times 10^{-2} \mathrm{~mm}$ (see figure 23 ).

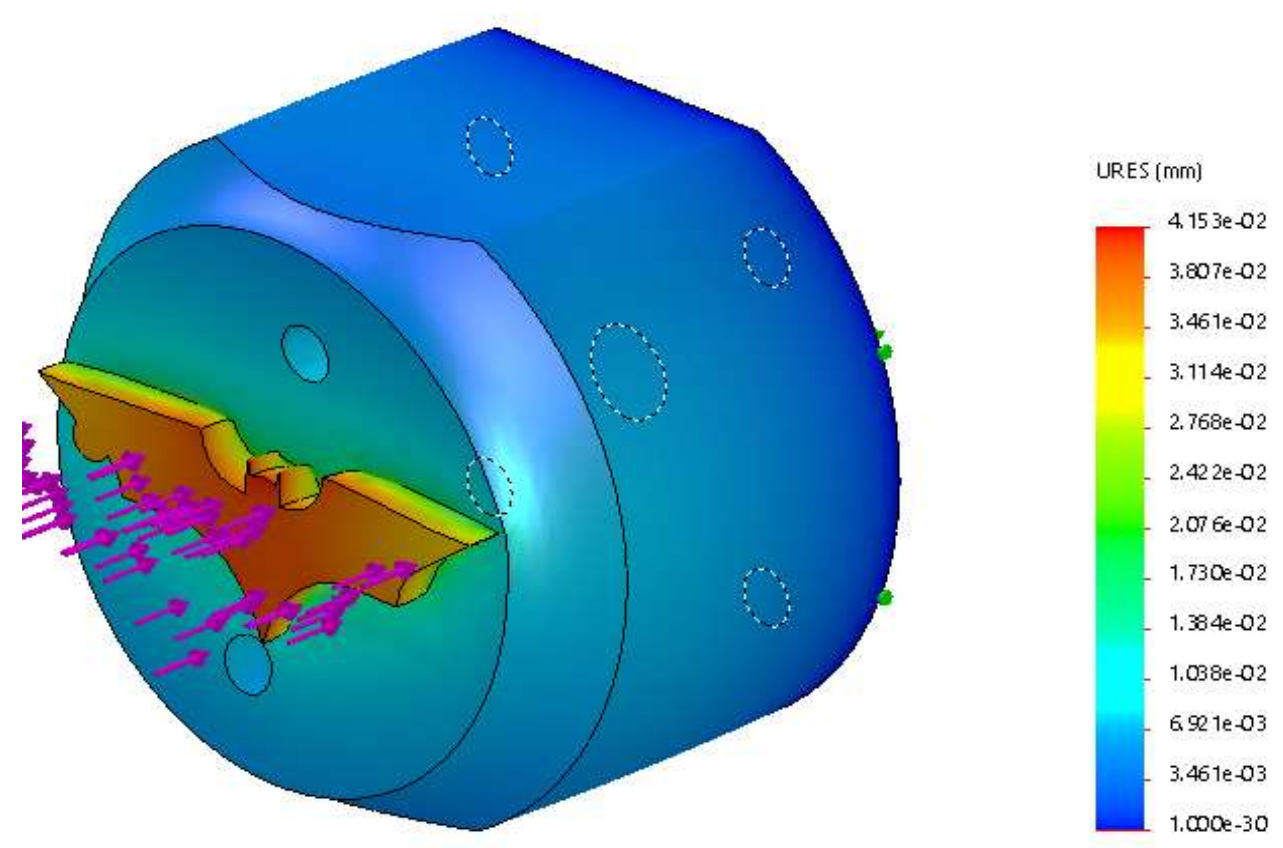

Figure 23 Displacement suffered by the part, according to static simulation. The authors.

The maximum strain was $2.002 \times 10^{-3}$, as shown in figure 24 . 
Año 13.

Núm. 33
Revista de Investigación

Académica sin Frontera

ISSN: 2007-8870

\section{https://revistainvestigacionacademicasinfrontera.unison.mx/index.php/RDIASF}

Recibido el 28 de junio de 2020. Dictaminado mediante arbitraje favorablemente 18 de diciembre de 2020.
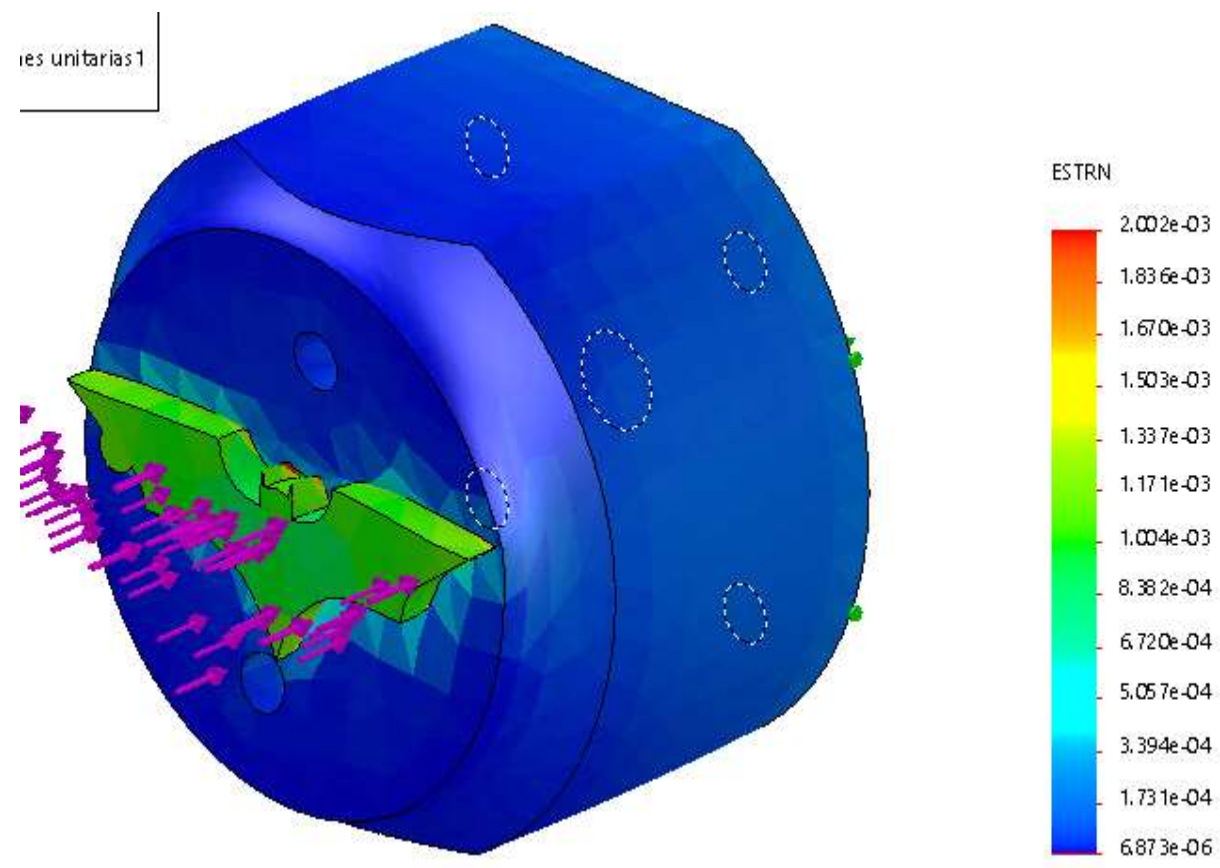

Figure 24 Strain result. The authors.

The fatigue results for accumulative damage for the events established above were $3.099 \times 10^{-1}$ as maximum (see figure 25).

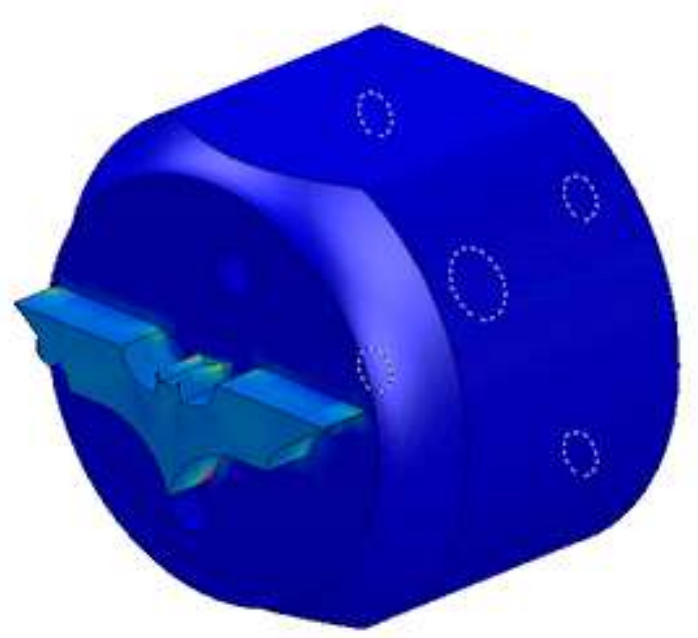

Figure 25 Result of the fatigue analysis. The authors. 
Año 13.

Núm. 33
Revista de Investigación

Académica sin Frontera

ISSN: 2007-8870

\section{https://revistainvestigacionacademicasinfrontera.unison.mx/index.php/RDIASF}

Recibido el 28 de junio de 2020. Dictaminado mediante arbitraje favorablemente 18 de diciembre de 2020.

\section{Stage V. Parts manufacturing.}

For the manufacturing stage, the pieces modeled in Solidworks were converted to ".stl" format as shown in figure 26. Later they were exported to Ultimaker Cura software as shown in figure 27.

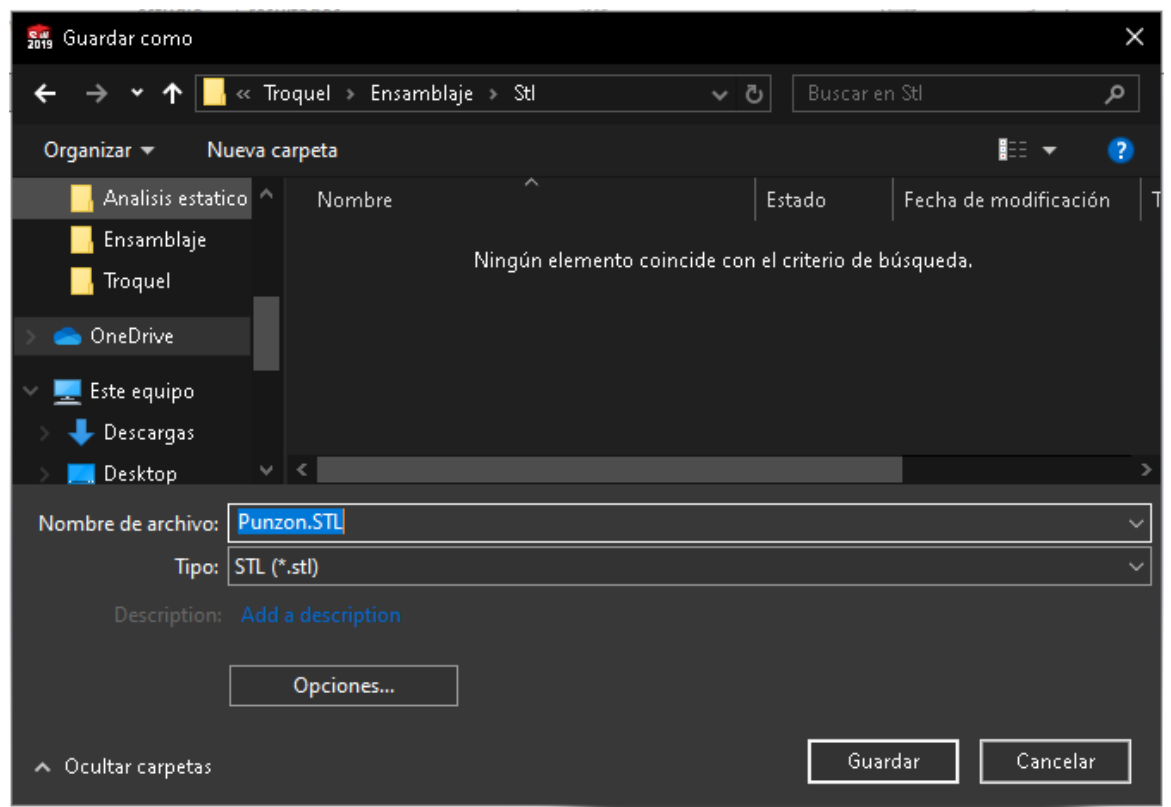

Figure 26 Conversion of models to ".stl” format from Solidworks. The authors.

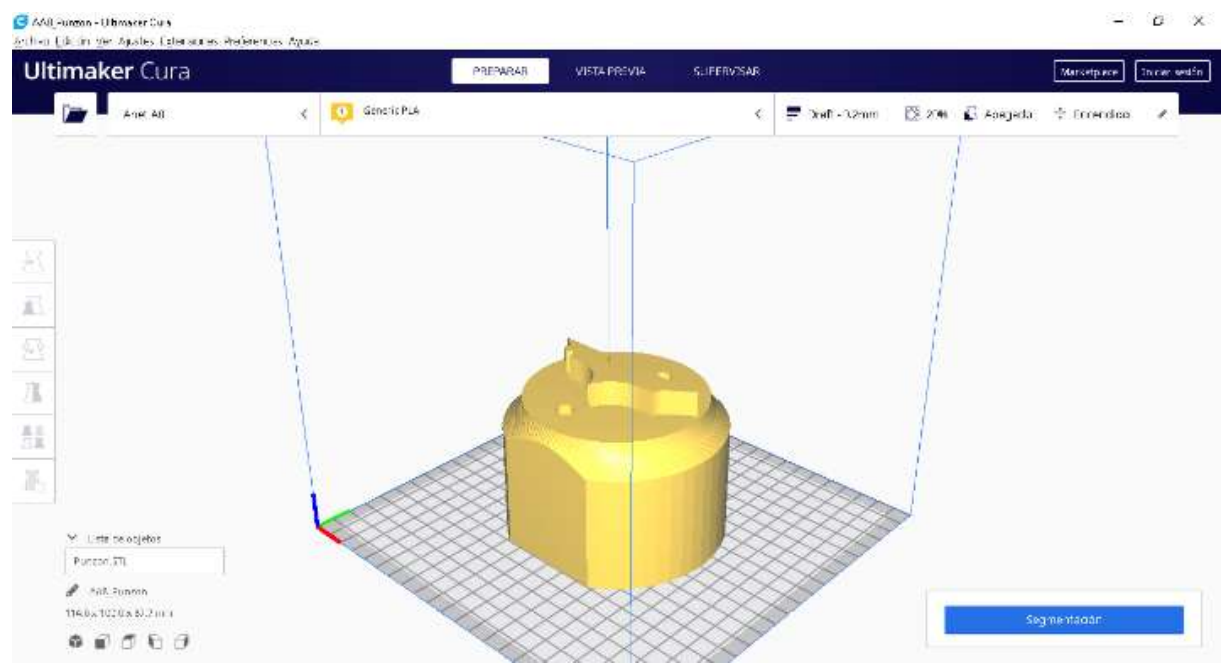

Figure 27 Punch part exported to Ultimaker Cura. The authors. 
Año 13.

Núm. 33
Revista de Investigación

Académica sin Frontera

ISSN: 2007-8870

\section{https://revistainvestigacionacademicasinfrontera.unison.mx/index.php/RDIASF}

Recibido el 28 de junio de 2020. Dictaminado mediante arbitraje favorablemente 18 de diciembre de 2020.

The material was selected from the Ultimaker Cura program interface, for this case PLA (polylactic acid) was used. Subsequently, the printing parameters were adjusted, as shown in figure 28 . The file was then saved in GCode generated by the program and the parts were printed.

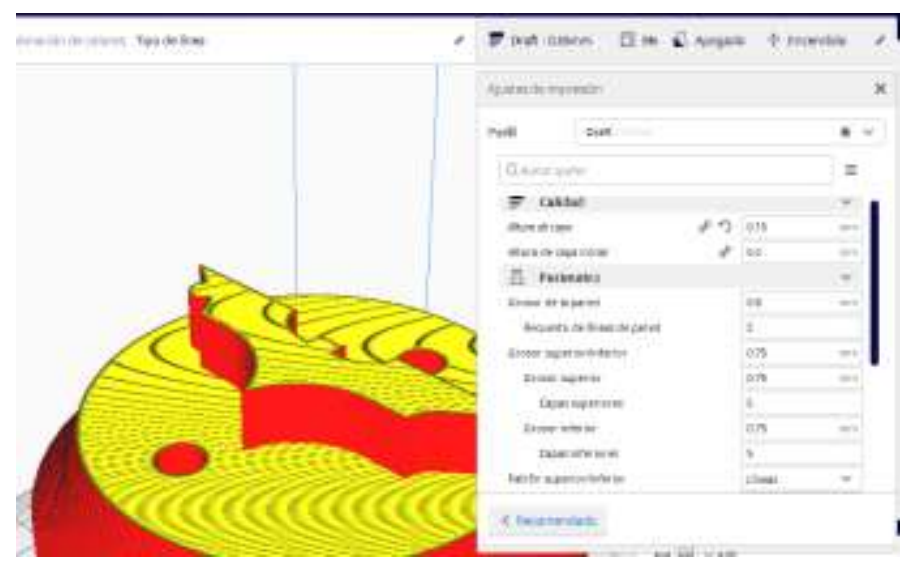

Figure 28 Print parameter settings. The authors.

The manufacturing results of the main parts are shown in figures 29,30 and 31 . The die assembly is shown in figure 32.

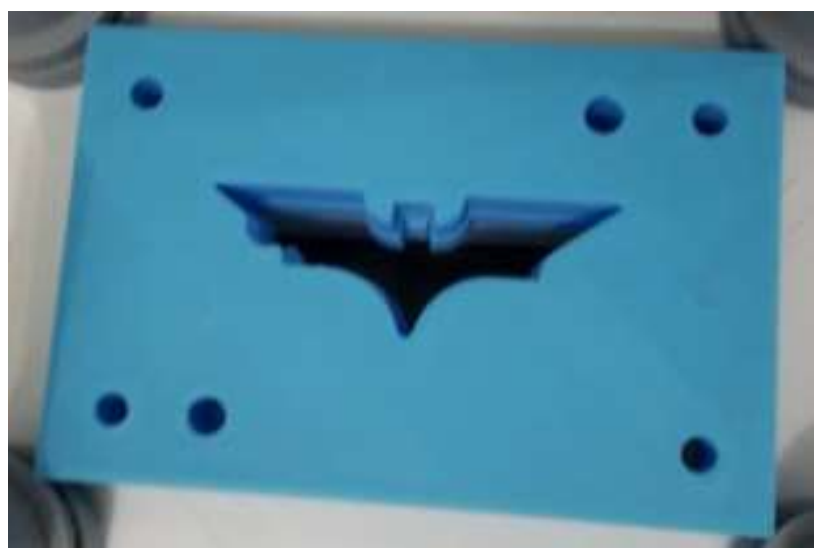

Figure 29 Die matrix. The authors. 
Año 13.

Núm. 33
Revista de Investigación

Académica sin Frontera

ISSN: 2007-8870

\section{https://revistainvestigacionacademicasinfrontera.unison.mx/index.php/RDIASF}

Recibido el 28 de junio de 2020. Dictaminado mediante arbitraje favorablemente 18 de diciembre de 2020.

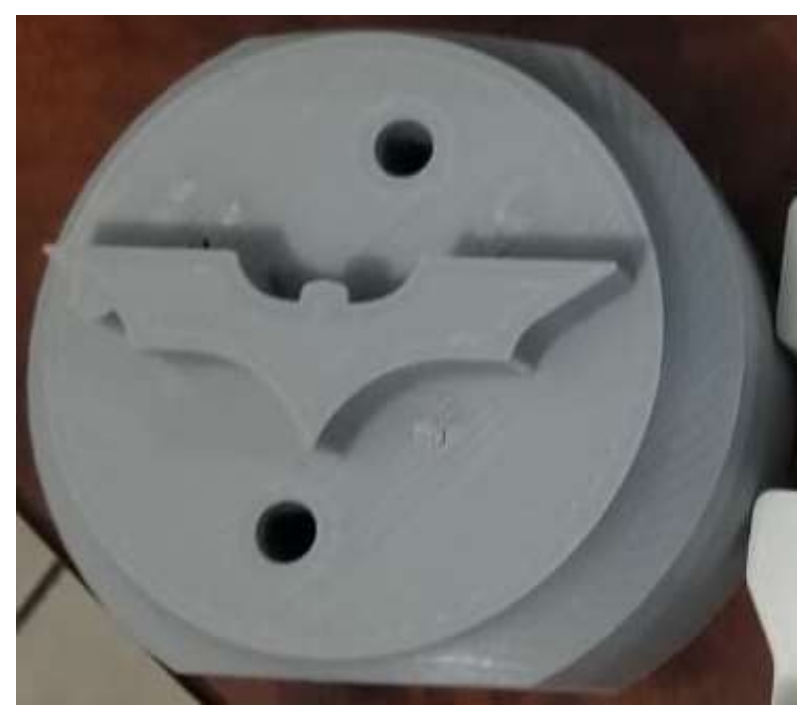

Figure 30 Die punch. The authors.

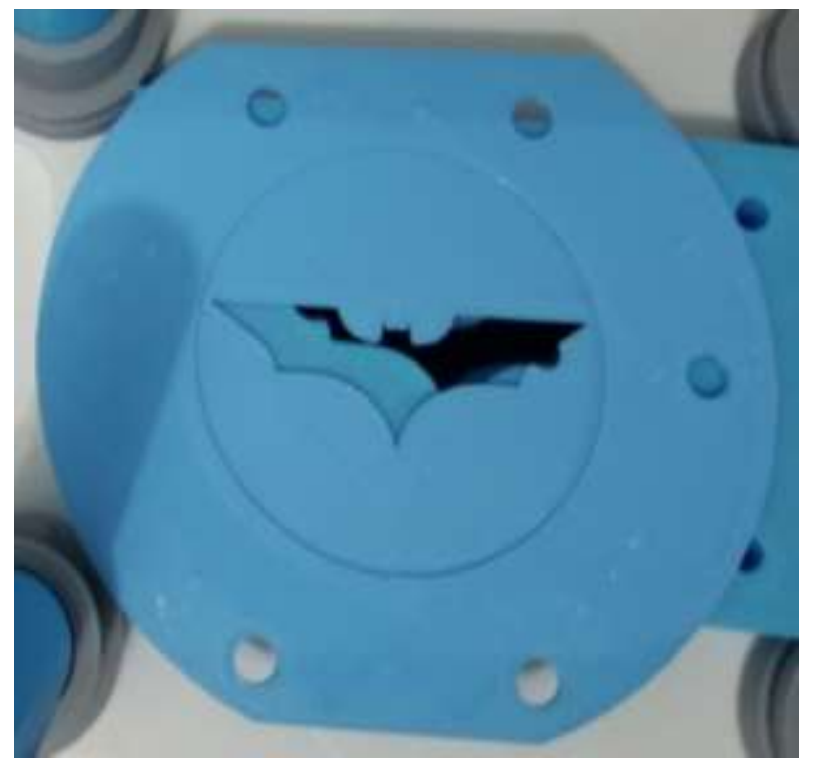

Figure 31 Die plunger. The authors 
Año 13.

Núm. 33
Revista de Investigación

Académica sin Frontera

ISSN: 2007-8870

\section{https://revistainvestigacionacademicasinfrontera.unison.mx/index.php/RDIASF}

Recibido el 28 de junio de 2020. Dictaminado mediante arbitraje favorablemente 18 de diciembre de 2020.

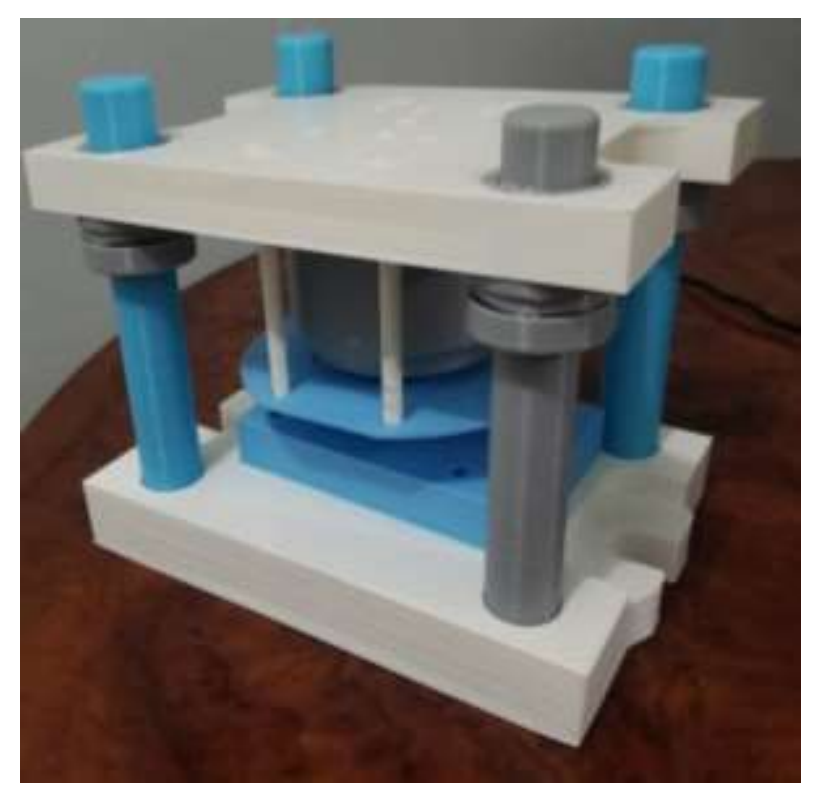

Figure 32 Complete die assembly. The authors.

\section{CONCLUSIONS}

A didactic die prototype was manufactured, oriented to the competencies required by the subject of precision mechanical design in mechatronic engineering at the Hermosillo Technological Institute, specifically unit 2 related to dies. The lessons that can be achieved with this methodology in the field of precision mechanical design are the following:

1. Theoretical calculation of the punch and the die matrix, fundamental parts in the operation of sheet metal manufacturing.

2. CAD design and modeling of die parts.

3. Validation with finite element analysis in specialized software; compression and fatigue analysis.

4. Manufacture of previously validated mechanical elements, with additive manufacturing tools.

5. Identification of the parts and the operation of the die, by means of the virtual and physical assembly of the die. 


\section{https://revistainvestigacionacademicasinf rontera.unison.mx/index.php/RDIASF}

Recibido el 28 de junio de 2020. Dictaminado mediante arbitraje favorablemente 18 de diciembre de 2020.

Design and modeling software, finite element analysis simulators, and polymeric materials printing technologies are important tools for the development of the engineer in the classroom, especially for solving problems related to the lack of infrastructure in schools. laboratories of public educational institutions, where it becomes problematic to carry out practices oriented to the competencies of each educational program (Chávez et al., 2019).

The advantage of this prototype, compared to metal stamping machines, is its low production and manufacturing cost; No expensive and specialized machinery is required for manufacturing, specific designs can be made by the students and their subsequent manufacturing (3D printing) in the mechatronics laboratory for free. The methodology can also be replicated in matters such as properties of materials, manufacturing processes and resistance of materials, taught in mechanical, aeronautical and industrial engineering within the Technological Institutes system.

\section{References}

Aguayo, S. (2014). El conformado en frío por embutición en la industria conservera (Tésis de grado). Universidad del Bío-Bío, Chile. Almattar, T. (2019). Learn Solidworks 2020 ( $1^{\mathrm{a}}$ ed.). PACKT PUBLISHING LIMITED.

Almeida, P. (2017). Ferramentaria de Corte, Dobra e Repuxo: Fundamentos técnicos, cálculos, máquinas e materiais utilizados ( $1^{\mathrm{a}}$ ed.). Saraiva.

Archuleta, M. (2015). Diseño y manufactura de un troquel de corte con fines didácticos (Tésis de grado). Universidad Autónoma de México, Ciudad de México.

Basco, A., Beliz, G., Coatz, D., \& Garnero, P. (2018). Industria 4.0: Fabricando el Futuro (1 ${ }^{\text {a }}$ ed., p. 27). Unión Industrial Argentina.

Boljanovic, V. \& Paquin, J. (2006). Die design fundamentals (3rd ed.). Industrial Press Inc.

Cabrera, J., Sánchez, I., Medina, F., \& Arias, J. (2017). Prototipo de guía didáctica para la enseñanza aprendizaje de la Física en ingeniería mediada por herramientas digitales disponibles en la web -Uso de simuladores. 4To Congreso Internacional Amitic 2017, 132-141.

Chávez, R., Villaseñor, J., \& Bracamontes, H. (2019). Prototipo didáctico de control de motores de inducción trifásicos. Pistas Educativas, 41(134), 928-943.

Estrada, R., Rodríguez, J., Lengarán, Y., \& Campos, S. (2017). Mitigation of the collapse of asbestos cement light covers by hurricane winds. Informes De La Construcción, 69(547). 
Año 13.

Núm. 33

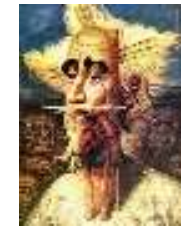

Revista de Investigación

Académica sin Frontera

ISSN: 2007-8870

\section{https://revistainvestigacionacademicasinfrontera.unison.mx/index.php/RDIASF}

Recibido el 28 de junio de 2020. Dictaminado mediante arbitraje favorablemente 18 de diciembre de 2020.

Ginjaume, A., \& Torre, F. (2005). Ejecución de procesos de mecanizado, conformado y montaje ( $2^{\mathrm{a}}$ ed., p. 430). Cengage Learning Paraninfo.

Gutiérrez-Rodríguez, C. (2018). Fortalecimiento de las competencias de interpretación y solución de problemas mediante un entorno virtual de aprendizaje. Revista de Investigación, Desarrollo e Innovación, 8 (2), 279-293.

Murakami, Y., \& Miller, K. J. (2005). "What is fatigue damage? A view point from the observation of low cycle fatigue process". International Journal of Fatigue. 27 (8): 991-1005.

Niño, J., \& Fernández, F. (2019). Una mirada a la enseñanza de conceptos científicos y tecnológicos a través del material didáctico utilizado. Revista Espacios, 4(15), 4.

Planchard, D. (2020). SolidWorks 2020 tutorial (1 $1^{\mathrm{a}}$ ed.). SDC Publications.

Rodríguez-Cepeda, R. (2016). Aprendizaje de conceptos químicos: una visión desde los trabajos prácticos y los estilos de aprendizaje. Revista de Investigación, Desarrollo e Innovación, 7 (1), 63-76.

Sierra, M., Adame, J., Pantoja, L., \& Valvantín, A. (2019). Diseño y construcción de un prototipo mecánico para pruebas de compresión de materiales poliméricos. Jóvenes En La Ciencia, 5, 1-5.

Solano-Villanueva, C. A., Casas-Díaz, J. F., \& Guevara-Bolaños, J. C. (2015). Aplicación móvil de realidad aumentada para la enseñanza de la clasificación de los seres vivos a niños de tercer grado. Ingeniería, 20 (1), 101-105.

Solidworks. (2018 a). Realizar análisis estático. Help.solidworks.com. Revisado el 10 Enero 2020,http://help.solidworks.com/2018/spanish/SolidWorks/cworks/t_Performing_Static_Analysis.htm

Solidworks. (2018 b). Componentes de deformación unitaria. Help.solidworks.com. Revisado 10 enero 2020, en http://help.solidworks.com/2018/spanish/solidworks/cworks/c_strain_components.htm

Solidworks. (2018 c). Criterio de máxima tensión de von Mises. Help.solidworks.com. Revisado 10 enero 2020 , http://help.solidworks.com/2018/spanish/solidworks/cworks/r_maximum_von_mises_stress_criterion.h tm

Solidworks. (2018 d). Tensión y deformación unitaria. Help.solidworks.com. Revisado 10 enero 2020, en http://help.solidworks.com/2018/spanish/solidworks/cworks/c_stress_strain.htm

Solidworks. (2018 e). Análisis de fatiga. Help.solidworks.com. Revisado el 12 enero 2020, http://help.solidworks.com/2018/spanish/SolidWorks/cworks/HelpViewerDS.aspx?version=2018\&pro $\mathrm{d}=$ SolidWorks\&lang=spanish\&path=cworks/c_Fatigue_Analysis.htm\&id=fa6b437f9cf64414b346382a 92c934a9 
Año 13.

Núm. 33
Revista de Investigación

Académica sin Frontera

ISSN: 2007-8870

\section{https://revistainvestigacionacademicasinf rontera.unison.mx/index.php/RDIASF}

Recibido el 28 de junio de 2020. Dictaminado mediante arbitraje favorablemente 18 de diciembre de 2020.

Solidworks. (2018 f). Realizar análisis de fatiga. Help.solidworks.com. Revisado 12 enero 2020, http://help.solidworks.com/2018/spanish/SolidWorks/cworks/t_Performing_Fatigue_Analysis.htm

Solidworks. (2018 g). Teoría del daño acumulativo. Revisado 12 enero 2020, http://help.solidworks.com/2018/spanish/SolidWorks/cworks/c_Theory_of_Cumulative_Damage.htm

Solidworks. (2018 h). Malla sólida. Help.solidworks.com. Revisado 16 marzo 2020, http://help.solidworks.com/2018/spanish/SolidWorks/cworks/c_Solid_Mesh.htm?verRedirect=1

Tangarife-Chalarca, D. (2013). Desarrollo de una aplicación web para el montaje de una mesa quirúrgica en el área de traumatología. Revista de Investigación, Desarrollo e Innovación, 4 (1), 32-44.

Tecnológico Nacional de México. (2015). Manual de Lineamientos Académico- Administrativos del Tecnológico Nacional de México. (2 edición). TecNM.

Tran, P. (2020). Solidworks 2020 Advanced Techniques (1 ${ }^{\mathrm{a}}$ ed.). SDC Publications. 
Año 13.

Núm. 33
Académica sin Frontera

ISSN: 2007-8870

https://revistainvestigacionacademicasinfrontera.unison.mx/index.php/RDIASF

Recibido el 28 de junio de 2020. Dictaminado mediante arbitraje favorablemente 18 de diciembre de 2020.

\section{Directorio Institucional}

Dr. Enrique Fernando Velázquez Contreras

Rector

Dr. Ramón Enrique Robles Zepeda

Secretario General Académico

Dra. Rosa María Montesinos Cisneros

Secretaria General Administrativa

\section{Dr. Rodolfo Basurto Álvarez}

Director de Vinculación y Difusión

Dra. Adriana Leticia Navarro Verdugo

Vicerrectora de la Unidad Regional Sur

Dr. Ernesto Clark Valenzuela

Director de la División de Ciencias Económicas y Sociales

Dr. Francisco Espinoza Morales

Secretario de la División de Ciencias Económico y Sociales

Dra. Leticia María González Velásquez

Jefe del Departamento de Ciencias Económico Administrativas

Dra. Lidia Amalia Zallas Esquer

Jefe de Departamento de Ciencias Sociales 
Año 13.

Núm. 33
Revista de Investigación

Académica sin Frontera

ISSN: 2007-8870

https://revistainvestigacionacademicasinfrontera.unison.mx/index.php/RDIASF

Recibido el 28 de junio de 2020. Dictaminado mediante arbitraje favorablemente 18 de diciembre de 2020.

\title{
Comité Directivo
}

\author{
Editor Responsable \\ Dr. Francisco Espinoza Morales \\ Universidad de Sonora \\ Directora \\ Dra. Leticia María González Velásquez \\ Universidad de Sonora \\ Subdirector \\ Dr. Javier Carreón Guillen \\ Universidad Nacional Autónoma de México \\ Editor Científico \\ Dr. Cruz García Lirios \\ Universidad Autónoma del estado de México \\ Master Gráfico \\ M.T.I. Francisco Alan Espinoza Zallas \\ Universidad Estatal de Sonora
}

Nos complace anunciar que su diario, "Academic Research Journal Withoutborders" (ISSN/EISSN 2007-8870) fue evaluado positivamente en la indexación Citefactor, ahora la página de la revista está disponible en línea, en caso de cualquier problema.

Journals Master | International Innovative Journal Impact Factor (IIJIF)

\section{Red Latinoamericana de revistas Académicas en Ciencias Sociales y Humanidades}

CiteFactor

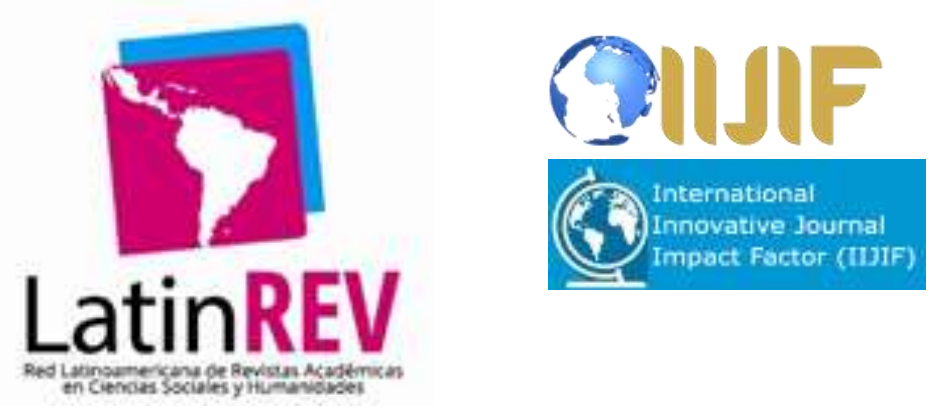




\section{https://revistainvestigacionacademicasinfrontera.unison.mx/index.php/RDIASF}

\section{Comité editorial}

Dra. Angélica María Rascón Larios

Universidad de Sonora. México

Dra. María del Rosario Molina González

Universidad de Sonora

Dra. Francisca Elena Rochin Wong

Universidad de Sonora. México

Dra. Lidia Amalia Zallas Esquer

Universidad de Sonora. México

Dra. Beatriz Llamas Arechiga

Universidad de Sonora. México

\section{Dr. Rogelio Barba Álvarez}

Universidad de Guadalajara. México

\section{Dra. Rosa María Rincón Ornelas}

Universidad de Sonora. México

Dr. Juan Flores Preciado

Universidad de Colima. México

Dr. Amado Olivares Leal. Universidad de Sonora

Universidad de Sonora. México

Dr. Guillermo Velázquez Valadez.

Instituto Politécnico Nacional (IPN) México

Dr. Hugo Nefstalí Padilla Torres.

Universidad Estatal de Sonora. México

Dr. Luis Ramón Moreno Moreno.

Universidad Autónoma de Baja California. México

Dr. Miguel Ángel Vázquez Ruiz.

Universidad de Sonora. México

Dra. Lorena Vélez García.

Universidad Autónoma de Baja California. México

Dra. Pabla Peralta Miranda.

Universidad Simón Bolívar, Barranquilla, Colombia

Mtro. Roberto Espíritu Olmos

Universidad de Colima (FCA Tecomán) Colima 
Año 13.

Núm. 33
Revista de Investigación

Académica sin Frontera

ISSN: 2007-8870

\title{
https://revistainvestigacionacademicasinfrontera.unison.mx/index.php/RDIASF
}

Recibido el 28 de junio de 2020. Dictaminado mediante arbitraje favorablemente 18 de diciembre de 2020.

\author{
Dr. Héctor Priego Huertas. \\ Universidad de Colima (FCA Tecomán) Colima
}

Mtra. María Guadalupe Alvarado Ibarra.

Universidad de Sonora. México.

MSc. Celso Germán Sánchez Zayas

Universidad de Camagüey, Ignacio Agramonte Loynaz, Cuba

Dra. María Luisa Quintero Soto

Universidad Autónoma del Estado de México

Dr. Eyder Bolivar Mojica

Universidad Católica, Luis Amigó, Medellin, Colombia

Revisores de Textos en Inglés

Mtro. Renato Encinas

Mtra. Cecilia Guadalupe Martínez Solano

\section{Comité Científico}

Dr. Rosendo Martínez Jiménez. Universidad Autónoma Benito Juárez de Oaxaca.

Dr. Hugo Neftalí Padilla. Universidad Estatal de Sonora

Dra. María Teresa Gaxiola Sánchez. Universidad de Sonora.

Dr. José Cesar Kaplan. Universidad Estatal de Sonora.

Dr. Alfredo Islas Rodríguez. Universidad de Sonora

Frecuencia de publicación: semestral / 2 números por año.

Revista de Investigación Académica sin Frontera (RIASF) con (ISSN: 2007-8870) es un interlocutor internacional de acceso abierto revisado diario en línea en el ámbito del de las Ciencias Económicas Administrativas y Sociales. Su objetivo principal es dar a los trabajos de investigación de calidad. Cubre todas las sub-campos de los campos anteriormente mencionados. Proporciona la plataforma a académicos, estudiantes y profesionales. Sólo pública trabajos de investigación y artículos de revisión inicial. Documento presentado debe cumplir con algunos criterios como, debe ser original, inédita y no estén sometidos a ninguna otra revista.

RIASF es una revista arbitrada / Revisión por pares International. Publicamos documentos sobre una variedad de temas, contextos y estrategias de análisis que examinan la relación entre la rápida evolución para la Sociedad y la tecnología del conocimiento. 
Año 13.

Núm. 33

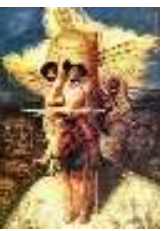

Revista de Investigación

Académica sin Frontera

ISSN: 2007-8870

\section{https://revistainvestigacionacademicasinfrontera.unison.mx/index.php/RDIASF}

Recibido el 28 de junio de 2020. Dictaminado mediante arbitraje favorablemente 18 de diciembre de 2020.

REVISTA DE INVESTIGACIÓN ACADÉMICA SIN FRONTERA, Año 13, No. 33, Julio - diciembre 2020, es una publicación semestral de investigación científica, editada por la Universidad de Sonora, a través de las División de Ciencias Económicas y Sociales, de la Unidad Regional Sur, Blvd. Lázaro Cárdenas No. 100, Col. Francisco Villa, Navojoa, Sonora, Sonora, México, C.P. 85880. Tel. (642) 425-99-54.

https://revistainvestigacionacademicasinfrontera.unison.mx/index.php/RDIASF, revistaacademicasinfrontera@unison.mx. Editor responsable: Francisco Espinoza Morales. Reserva de Derechos al Uso Exclusivo: 04-2013121811323700-203 e ISSN: 2007-8870, ambos otorgados por el Instituto Nacional de Derecho de Autor. Inscrita en el Directorio de LATINDEX, con Núm. De folio 20014, folio único 14590. Responsable de la última actualización de este Número, Unidad Informática de la Universidad de Sonora, fecha de la última modificación, 30 de diciembre 2020, indexada a Cite Factor Academic Scientific Journal y Journals Master (IIJIF) y Red Latinoamericana de Revistas Académicas en Ciencias Sociales y Humanidades, (Latín Rev). Las opiniones expresadas por los autores no necesariamente reflejan la postura del editor de la publicación. Se autoriza la reproducción total o parcial de los contenidos e imágenes en la presente publicación siempre y cuando se cuente con la autorización del editor y se cite plenamente la fuente.

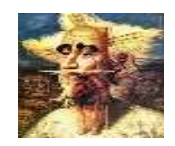

Nos complace anunciar que su diario, "Academic Research Journal Withoutborders" (ISSN/EISSN 2007-8870) fue evaluado positivamente en la indexación Citefactor, ahora la página de la revista está disponible en línea, en caso de cualquier problema.

\section{Journals Master | International Innovative Journal Impact Factor (IIJIF)}

\section{Red Latinoamericana de revistas Académicas en Ciencias Sociales y Humanidades}

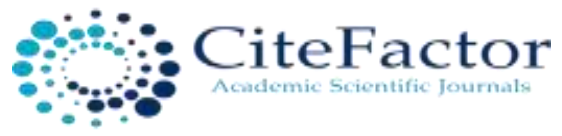

\section{ES.JI www.ESJIndex.org}

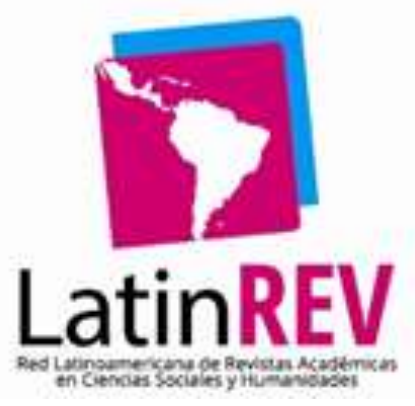

latindex

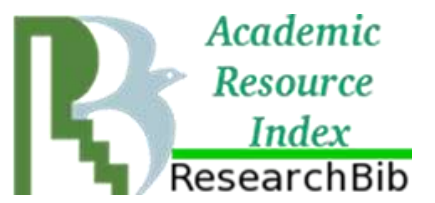

